University of Louisville

ThinkIR: The University of Louisville's Institutional Repository

Electronic Theses and Dissertations

8-2017

\title{
The comparative cytotoxicity and genotoxicity of hexavalent chromium in humans and sea turtles.
}

Rachel M. Speer

University of Louisville

Follow this and additional works at: https://ir.library.louisville.edu/etd

Part of the Environmental Health Commons, and the Toxicology Commons

\section{Recommended Citation}

Speer, Rachel M., "The comparative cytotoxicity and genotoxicity of hexavalent chromium in humans and sea turtles." (2017). Electronic Theses and Dissertations. Paper 2808.

https://doi.org/10.18297/etd/2808

This Master's Thesis is brought to you for free and open access by ThinkIR: The University of Louisville's Institutional Repository. It has been accepted for inclusion in Electronic Theses and Dissertations by an authorized administrator of ThinkIR: The University of Louisville's Institutional Repository. This title appears here courtesy of the author, who has retained all other copyrights. For more information, please contact thinkir@louisville.edu. 


\title{
THE COMPARATIVE CYTOTOXICITY AND GENOTOXICITY OF HEXAVALENT CHROMIUM IN HUMANS AND SEA TURTLES
}

\section{By}

\author{
Rachel M. Speer
}

B.S. Rochester Institute of Technology, 2013

\author{
A Thesis \\ Submitted to the Faculty of the \\ School of Medicine of the University of Louisville \\ in Partial Fulfillment of the Requirements \\ For the Degree of \\ Master of Science in Pharmacology and Toxicology \\ Department of Pharmacology and Toxicology \\ University of Louisville \\ Louisville, Kentucky
}

August 2017 
Copyright 2017 by Rachel M. Speer

All Rights Reserved 

THE COMPARATIVE CYTOTOXICITY AND GENOTOXICITY OF HEXAVALENT CHROMIUM IN HUMANS AND SEA TURTLES

By

Rachel M. Speer

B.S. Rochester Institute of Technology, 2013

A Thesis Approved on

June 14, 2017

by the following Thesis Committee:

John Pierce Wise, Sr., Ph.D.

J. Christopher States, Ph.D.

Levi Beverly, Ph.D.

Juliane Beier-Arteel, Ph.D.

Qunwei Zhang, Ph.D 


\section{ACKNOWLEDGEMENTS}

I would first like to thank my mentor, John Wise, for all of the incredible experiences and opportunities I have had over the past few years as a part of the Wise Laboratory. It has surely been an adventure and has provided learning experiences that extend past the bench into life lessons and growth. Additionally, much of this work would not have been possible without the incredible support and collaboration with those at the U.S. Fish and Wildlife Service, Vieques, Puerto Rico. Thank you Eric and Mike for guiding our field work efforts and providing extended opportunities to engage in your community and research. In hand, I also have to thank Mark, Lirio, and all those at the Vieques Conservation and Historical Trust for welcoming the Wise Laboratory to collaborate in our research and community engagement efforts and providing laboratory space to carry out our field work.

Undoubtedly, I have to thank my mom and dad who despite the distance have always been supporting and encouraging in my educational and career endeavors. Finally, Suleiman and Sharlie, I have you to thank for nurturing and supporting my day-to-day that unquestionably has created an enriched environment to pursue my educational efforts. Much love to you all. 


\begin{abstract}
THE COMPARATIVE CYTOTOXICITY AND GENOTOXICITY OF HEXAVALENT CHROMIUM IN HUMANS AND SEA TURTLES

Rachel M. Speer

June 14, 2017
\end{abstract}

Monitoring the health effects of environmental contaminants can be achieved using sentinel species as models. Leatherback sea turtles (Dermochelys coriacea) are an endangered marine species that may experience prolonged exposures to environmental contaminants including hexavalent chromium [Cr(VI)]. While $\mathrm{Cr}(\mathrm{VI})$ has been identified as a known human carcinogen, the health effects in marine species are poorly understood. In this study the cytotoxic and genotoxic effects of particulate and soluble $\mathrm{Cr}(\mathrm{VI})$ were assessed in leatherback lung cells and compared to those in human lung cells. $\mathrm{Cr}(\mathrm{VI})$ induced a concentration-dependent increase in cytotoxicity and genotoxicity in leatherback lung cells indicating $\mathrm{Cr}(\mathrm{VI})$ may be a health concern for leatherbacks and other long-lived marine species. Additionally, these results were comparable to those in humans. Based on these results leatherbacks are an ideal model species for monitoring the health effects of $\mathrm{Cr}(\mathrm{VI})$ and therefore serve as an indicator species for environmental human exposures. 


\section{TABLE OF CONTENTS}

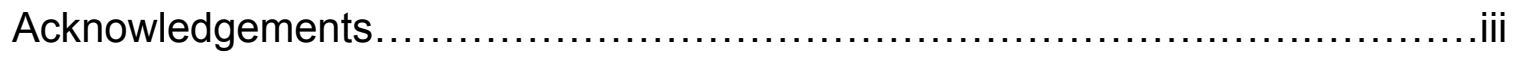

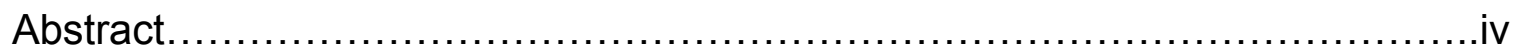

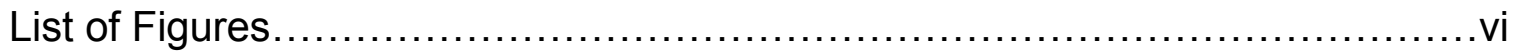

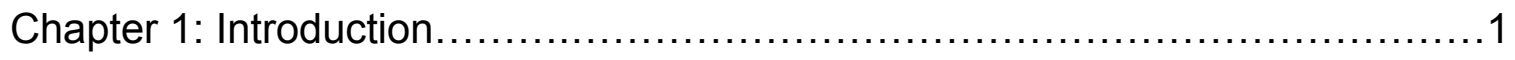

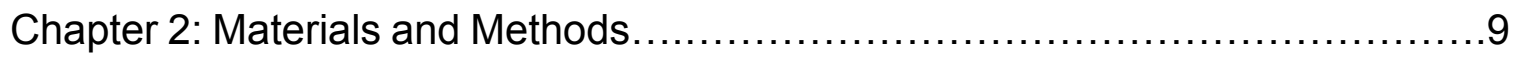

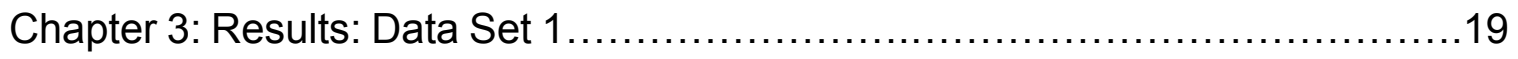

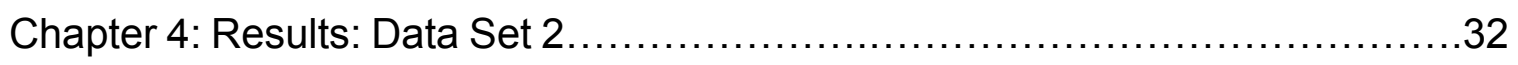

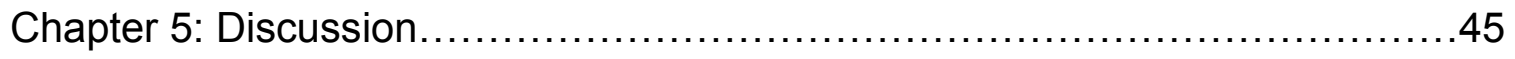

Chapter 6: Summary and Conclusions............................................59

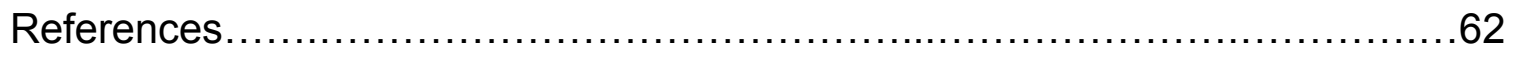

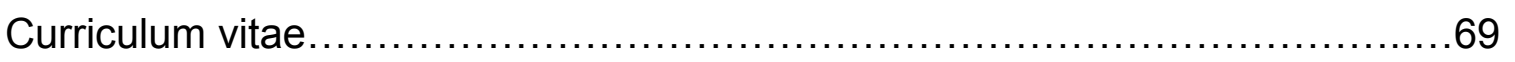




\section{LIST OF FIGURES}

1. One Health Approach

2. Physico-Chemico Properties of Chromium

3. Intracellular Reduction of Hexavalent Chromium

4. Cytotoxicity Assay

5. Types of Chromosome Damage

6. Types of Metaphases Damage

7. Particulate and Soluble Chromate are Cytotoxic to Leatherback Sea Turtle Lung Cells

8. Particulate and Soluble Chromate are Genotoxic to Leatherback Sea Turtle Lung Cells

9. Intracellular Chromium Ion Concentrations Increase with Increasing Particulate and Soluble Chromate Treatment.

10. Particulate and Soluble Chromium Induce Varying Levels of Cytotoxicity and Genotoxicity in Leatherback Sea Turtle Lung Cells

11. Particulate Chromate is Cytotoxic to Leatherback Sea Turtle and Human Lung Cells

12. Particulate Chromate Incudes Genotoxicity in Leatherback Sea Turtle and Human Lung Cells

13. Leatherback Sea Turtle and Human Lung Cells Accumulate Similar Levels of Intracellular Chromium

14. Particulate Chromate Induces Similar Trends of Cytotoxicity in Leatherback Sea Turtle and Human Lung Cells

15. Particulate Chromate Induces Similar Levels of Genotoxicity in Leatherback Sea Turtle and Human Lung Cells 


\section{CHAPTER 1: INTRODUCTION}

\subsection{The One Health Approach}

The One Environmental Health approach incorporates considerations of the health of humans, wildlife, and the ecosystem to gain a comprehensive view of total health (Figure 1). Wildlife species are commonly used as sentinels to monitor the health of the environment [1-4]. Specifically, the application of studying marine species provides a look into the health of the oceans and potential threats that may be affecting both wildlife species and humans [5-7]. The One Health concept aims to incorporate these interdisciplinary approaches and diverse research perspectives to consider all aspects of health.

While the focus of One Health has heavily been on infectious disease this approach is being increasingly expanded to toxicological research. There have been many case reports of poisoning events and toxicological monitoring using wildlife species around the world. For example, cattle and horses in Minnesota in the 1960 s were found to have lead poisoning leading to close monitoring of the human population [8]. Similarly, dichlorodiphenyltrichloroethane (DDT) and polychlorinated biphenyls (PCBs) have been widely documented in marine mammals to evaluate environmental contamination and to assess human health risks [9]. Here, the One Health approach was applied using leatherback sea turtles as a model species to understand the threat of metal pollution to them, to monitor 
the health of the oceans, and to better understand human health in the environment.

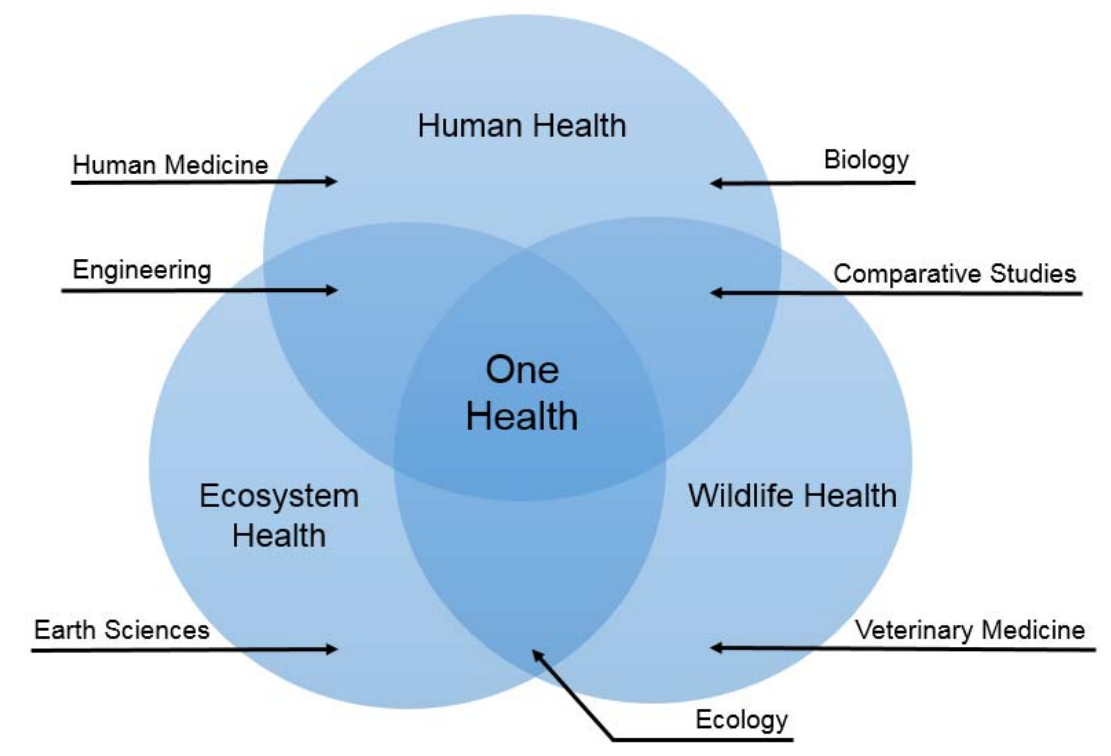

\section{Figure 1. One Health Approach}

This figure shows a schematic of the One Health Approach including areas of study in each related field. This figure demonstrates that there are multiple areas of research that can be utilized together to gain an overall view of one health.

\subsection{Chromium Exposure}

Chromium ( $\mathrm{Cr})$ is a metal that is found naturally in the Earth's crust and which has many desirable properties such as its hardness, resistance to corrosion, and bright colors [10]. It is widely used in many applications such as a coloring agent for paints and dyes, chrome plating, leather tanning, an anticorrosive agent for boats, aircraft, and military equipment, and it is a component of alloys used in joint replacement prosthetics [11,12]. As $\mathrm{Cr}$ is widely used in these applications exposure to it can be widespread. Humans and wildlife species may be exposed 
to $\mathrm{Cr}$ in the environment, while humans risk additional exposure in occupational settings where $\mathrm{Cr}$ is used.
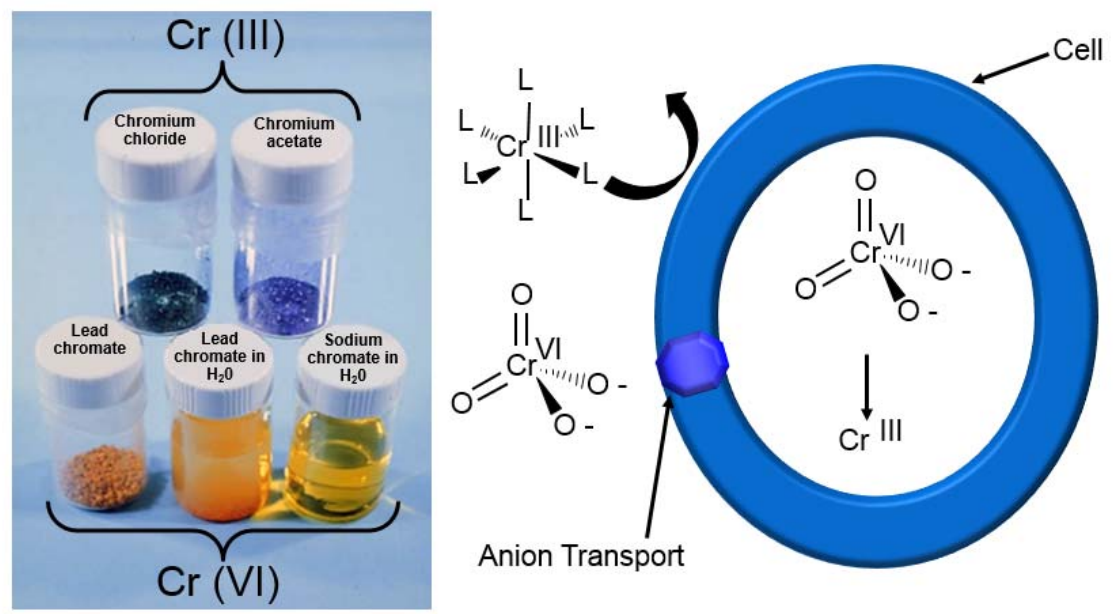

\section{Figure 2. Physico-Chemico Properties of Chromium}

This figure shows the two main properties of chromium that determine its toxicological effects including valence state and solubility. $\operatorname{Cr}(\mathrm{III})$ does not readily enter the cell because it binds ligands in the body making a bully molecule. $\mathrm{Cr}(\mathrm{VI})$, however, uses anion transport to readily enter cells where it is reduced to $\operatorname{Cr}(I I I)$.

There are two main chemical-physico properties that affect the risks associated with $\mathrm{Cr}$ exposure; valence state and solubility (Figure 2). There are seven oxidation states of $\mathrm{Cr}$, of which only elemental $[\mathrm{Cr}(0)]$, trivalent chromium $[\mathrm{Cr}(\mathrm{III})]$, and hexavalent chromium [Cr( $\mathrm{VI})]$ are stable in the environment [13]. Aside from elemental $\mathrm{Cr}, \mathrm{Cr}(\mathrm{III})$ is the form commonly found in the environment and is generally considered to be safe to human health. The chemical structure of $\mathrm{Cr}(\mathrm{III})$ promotes it to bind to molecules extracellularly making it a bulky molecule unable to enter cells readily [14]. 
$\mathrm{Cr}(\mathrm{VI})$ is almost exclusively found in the environment as a result of human activities such as the burning of fossil fuels and other industrial processes. The structure of $\mathrm{Cr}(\mathrm{VI})$ mimics that of sulphate and phosphate groups. Therefore, chromate utilizes anion transport channels to enter cells though facilitated diffusion [14]. Once inside the cell, $\mathrm{Cr}(\mathrm{VI})$ is rapidly reduced by several different factors including ascorbate, $\mathrm{NADPH}$, and glutathione to $\mathrm{Cr}(\mathrm{III})$ [15]. During this process reactive oxygen species (ROS) are released and the $\mathrm{Cr}$ ion passes through two oxidation states $\mathrm{Cr}(\mathrm{V})$ and $\mathrm{Cr}(\mathrm{IV})$ before reaching stability as $\mathrm{Cr}(\mathrm{III})$ [15]. This reduction process of $\mathrm{Cr}(\mathrm{VI})$ to $\mathrm{Cr}(\mathrm{III})$ is thought to be responsible for the toxicities and carcinogenic effects associated with $\mathrm{Cr}(\mathrm{VI})$ exposure.

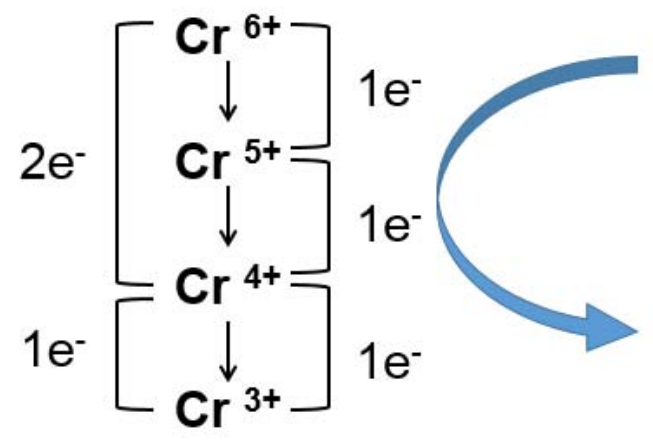

$\mathrm{Cr}(\mathrm{VI})$ is reduced by a reductant decreasing its oxidation state in one or two steps.

Reactive oxygen species and transient $\mathrm{Cr}$ intermediates are formed.

\section{Figure 3. Intracellular Reduction of Hexavalent Chromium}

This figure demonstrates the reduction process of $\operatorname{Cr}(\mathrm{VI})$ to $\operatorname{Cr}(\mathrm{III})$ that occurs intracellularly. This process results in the formation of reactive oxygen species and transient $\mathrm{Cr}$ intermediates including $\mathrm{Cr}(\mathrm{V})$ and $\mathrm{Cr}(\mathrm{IV})$ before reaching stability as $\mathrm{Cr}(\mathrm{III})$.

The second property that affects the risk of $\mathrm{Cr}(\mathrm{VI})$ exposure is solubility. $\mathrm{Cr}$ compounds range from completely soluble to insoluble with various degrees of solubility in between. Many metals including $\mathrm{Cr}$ have been shown to have different 
effects based on solubility [16-18]. For example, particulate $\mathrm{Cr}(\mathrm{VI})$ rather than soluble $\mathrm{Cr}(\mathrm{VI})$ is considered to be the most carcinogenic form. The rationale behind the higher carcinogenicity of particulate $\mathrm{Cr}(\mathrm{VI})$ is that particulate $\mathrm{Cr}(\mathrm{VI})$ deposits at sites in the body and does not rapidly dissolve leading to prolonged exposures [11]. Specifically, the deposition of particulate $\mathrm{Cr}(\mathrm{VI})$ and its slow release as it dissolves is associated with $\mathrm{Cr}(\mathrm{VI})$-induced lung cancer [11].

Exposure to $\mathrm{Cr}(\mathrm{VI})$ occurs predominantly through inhalation and ingestion and to a lesser degree dermal absorption [11]. Therefore, the health risks associated with $\mathrm{Cr}(\mathrm{VI})$ exposure follow accordingly. $\mathrm{Cr}(\mathrm{VI})$ is known to cause many respiratory effects such as asthma, chronic bronchitis and inflammation, ulceration of the nasal mucosa, and congestion [11]. $\mathrm{Cr}(\mathrm{VI})$ is a known human lung carcinogen inducing lung tumors characterized by genomic instability, and this outcome is well documented in chromate workers [19-21]. Furthermore, additional $\mathrm{Cr}(\mathrm{VI})$ health risks include developmental issues and immune system effects as well as renal and hepatic impairments $[11,22,23]$.

One area of recent and growing concern is low level, lifetime exposures that put both humans and wildlife, including leatherback sea turtles, at risk. The health status of the oceans has recently been changing at a faster rate due to climate change leading to concerns such as ocean acidification [24]. This process may lead to the release of hazardous compounds, such as $\mathrm{Cr}(\mathrm{VI})$, deposited in ocean sediments [25-27]. Hazardous compounds released from the sediments may suspend in the water column where leatherback sea turtles, a pelagic species, spend a majority of their time [28]. In addition to being released from ocean 
sediments $\mathrm{Cr}(\mathrm{VI})$ is also released into the environment through the burning of fossil fuels and other industrial processes [10,29-31]. Ultimately $\mathrm{Cr}(\mathrm{VI})$ released in this manner can travel through air currents around the world with the potential to settle in the oceans.

\subsection{Leatherback Sea Turtles}

Leatherback sea turtles (Dermochelys coriacea) are a large and long lived marine reptile that spend the entirety of their lives in the ocean except for when females lay their eggs. Leatherbacks are found throughout all of the world's oceans and commonly travel long distances during their lives. The extended amount of time leatherbacks spend in the ocean subjects them to exposure to pollutants and contaminants that may be present [32-38]. These pollutants have the potential to lead to detrimental health effects including reproductive issues $[34,38,39]$. Furthermore, leatherbacks may bioaccumulate environmental contaminants exacerbating health issues caused by exposure to environmental contaminants including $\mathrm{Cr}(\mathrm{VI})$.

It is important to study the potential effects of environmental contaminants on leatherback sea turtles in order to understand the potential impact on the health of their population, the health of their environment, and to gain insight into human health. Leatherback sea turtles are an endangered species and face many pressures due to human activity [40,41]. In addition to the health impacts from exposure to human-derived contaminants leatherback sea turtles face threats including plastic in the oceans, fishing entanglement, and habitat degradation 
$[42,43]$. Finally, reptiles tend to be more sensitive to chemical exposures in the environment and therefore serve as early indicators of toxic events [44].

Since leatherback sea turtles may experience prolonged exposure to $\mathrm{Cr}(\mathrm{VI})$ in the marine environment through the air, water, and food sources it is important to understand the potential health implications of this potential exposure. Several studies have investigated metal levels in leatherback sea turtles around the world and found their tissues can accumulate metals such as mercury, cadmium, lead, and arsenic [34-38,43-47]. To my knowledge only one study has investigated $\mathrm{Cr}$ levels in leatherback sea turtles, but did not measure Cr levels in lung tissue [47]. However, one study showed that in tissues of adult and young loggerhead sea turtles (Caretta caretta) $\mathrm{Cr}$ accumulated in the highest concentrations in the lung [48]. Another study found that $\mathrm{Cr}$ levels in the yolk of eggs from green sea turtles (Chelonia mydas) were considered above normal compared to levels observed in mammals and birds, however the effects of these levels remain unknown [49].

Previously, the Wise Laboratory found $\mathrm{Cr}(\mathrm{VI})$ was both cytotoxic and genotoxic to another sea turtle species, the hawksbill sea turtle (Eretmochelys imbricate) $[7,50]$. Additionally, no studies so far have investigated the effect of $\mathrm{Cr}(\mathrm{VI})$ in leatherback sea turtles. Therefore, in this study the cytotoxic and genotoxic effects of $\mathrm{Cr}(\mathrm{VI})$ in leatherback sea turtle lung cells were investigated and these effects were compared to those in human lung cells. These data will provide insight to the potential health effects of $\mathrm{Cr}(\mathrm{VI})$ to leatherback sea turtles and how they relate to human health. The data are presented in two sets. The first set encompasses a comparison between three chromate compounds, including both soluble and 
particulate forms, in leatherback sea turtles. The second data set is a comparison of the effects of one particulate chromate compound between leatherback sea turtle and human lung cells. 


\section{CHAPTER 2: MATERIALS AND METHODS}

\subsection{Chemicals and reagents}

DMEM/F12 (1X), phosphate-buffered solution (PBS) 1X without calcium or magnesium, Corning glutaGRO supplement (200 mM), tissue culture dishes, flasks and plasticware were purchased from Corning (Corning, NY). Sodium pyruvate (100 mM) was purchased from Lonza (Allendale, NJ). Gurr's buffer and $0.5 \%$ trypsin-EDTA (10X), and $0.25 \%$ trypsin-EDTA were purchased from Life Technologies Corp (Carlsbad, CA). Crystal violet and acetic acid were purchased from J.T. Baker (Phillipsburg, NJ). Lead chromate (CAS\#7758-97-6), sodium chromate (CAS\#7775-11-3), and demecolcine were purchased from SigmaAldrich (St. Louis, MO). Potassium chloride $(\mathrm{KCl})$ and zinc chromate was purchased from Alfa Aesar (CAS\#13530-65-9; ACS reagent minimum 98\% purity, Alfa Aesar, Ward Hill, MA). Giesma stain was purchased from Biomedical Specialties Inc. (Santa Monica, CA). Seradigm premium grade fetal bovine serum (FBS), Sodium dodecyl sulfate (SDS), and methanol were purchased from VWR International (Radnor, PA). Attachment factor was purchased from ThermoFisher Scientific (Waltham, MA). Trace-element grade nitric acid was purchased from Fischer Scientific (Hampton, NH). Cosmic calf serum (CCS) was purchased from Hyclone (Logan, UT). 


\subsection{Cell line development and cell culture}

Leatherback sea turtle primary lung cells were established from explant lung tissue derived from a leatherback sea turtle embryo and named PGDC9-1LU cells. PGDC9-1LU cells were maintained as sub-confluent monolayers in DMEM/F12 media supplemented with $10 \%$ fetal bovine serum, $1 \%$ penicillin/streptomycin, $1 \%$ glutaGRO, and $0.1 \%$ sodium pyruvate. PGDC9-1LU cells were incubated in $5 \%$ $\mathrm{CO}_{2}$ at $26^{\circ} \mathrm{C}$ and media were replaced with fresh, warm media every two to three days. Cells were subcultured every four to six days using $0.1 \%$ trypsin-EDTA. The cell line was evaluated for numerical and structural chromosome normality through subsequent passaging of the cells. All experiments were done in cells in passage 20 or less, and no aneuploidy or cellular morphological changes were observed in untreated cells.

Normal human lung fibroblasts (NHLFs) were used as a representative human lung cell line. NHLF cells are primary lung fibroblasts purchased from Lonza (Allendale, NJ; CAT\# CC-2512, LOT NO: 0000511473). The cells came from a 37 year old Caucasian man and the cells exhibit normal growth parameters and a

normal karyotype. NHLF cells were maintained as a monolayer in DMEM/F-12 supplemented with $15 \%$ CCS, $1 \%$ glutaGRO, $0.1 \mathrm{mM}$ sodium pyruvate, and $1 \%$ penicillin/streptomycin and fed every other day. Cells were subcultured every three to four days using $0.25 \%$ trypsin-EDTA. All experiments were maintained in a $37^{\circ} \mathrm{C}$, humidified incubator with $5 \% \mathrm{CO}_{2}$. 


\subsection{Chromium preparation}

Sodium chromate $\left(\mathrm{Na}_{2} \mathrm{CrO}_{4}\right)$ was used as a representative soluble $\mathrm{Cr}(\mathrm{VI})$ compound. Solutions of sodium chromate were weighed and dissolved in doubledistilled water (18). Appropriate dilutions for each treatment concentration were made, then filter sterilized through a $10 \mathrm{ml}$ syringe with a 0.2 um filter. Sodium chromate is $100 \%$ soluble in water and was administered in micromolar $(\mu \mathrm{M})$ concentrations. Final chromate concentrations in cell culture ranged from 0-10 $\mu \mathrm{M}$ sodium chromate for the soluble chromate treatments.

Lead chromate $\left(\mathrm{PbCrO}_{4}\right)$ and zinc chromate $\left(\mathrm{ZnCrO}_{4}\right)$ were used as representative particulate $\mathrm{Cr}(\mathrm{VI})$ compounds and were administered as a suspension in water (18). Lead chromate and zinc chromate are insoluble in water and were therefore administered as weight per surface area $\left(\mu \mathrm{g} / \mathrm{cm}^{2}\right)$. Zinc chromate has a higher solubility factor than lead chromate and can therefore dissolve in cell culture media distinguishing it from lead chromate. Final chromate concentrations in cell culture ranged from $0-10 \mu \mathrm{g} / \mathrm{cm}^{2}$ for the lead chromate treatments and $0-0.4 \mu \mathrm{g} / \mathrm{cm}^{2}$ for the zinc chromate treatments; concentrations believed to be environmentally relevant ranges to which humans, sea turtles, and other wildlife species may be exposed.

Suspensions of lead or zinc chromate particles were prepared by rinsing twice in double-distilled water to remove any water-soluble contaminants. Then the particles were washed twice in acetone to remove any organic contaminants. The washed particles were air-dried, weighed, and placed in double-distilled water in a 
borosilicate scintillation vial and stirred overnight with a magnetic stir bar at $4^{\circ} \mathrm{C}$. In previous studies by the Wise Laboratory these methods were shown to result in particles in the size range of $0.2-2.3 \mu \mathrm{m}$ with a mean size of $2.7 \mu \mathrm{m}[49,50]$. During the preparation of the appropriate dilutions and during the treatment procedure the particles were kept in suspension using a vortex mixer. The dilutions were dispensed directly into cultures from these suspensions.

\subsection{Intracellular chromium ion measurements}

Intracellular chromium ion levels were determined by atomic absorption spectrometry (AAS). Cells were seeded at a density of 700,000 cells in a 100-mm tissue-culture dish and allowed to grow for $48 \mathrm{~h}$. Then the cells were treated with various concentrations of sodium chromate for $24 \mathrm{~h}$ or lead or zinc chromate for 0 $\mathrm{h}, 24 \mathrm{~h}$, or $120 \mathrm{~h}$ exposure periods. At the end of the treatment time $3 \mathrm{~mL}$ of media were collected using a $3 \mathrm{~mL}$ syringe and filtered through a $0.2 \mu \mathrm{m}$ filter into new tubes. Two $\mathrm{mL}$ of filtered media were placed in fresh tubes and diluted with $2 \mathrm{~mL}$ of $2 \%$ trace element grade nitric acid. Then the remaining media were collected to account for any detached or loosely adherent cells. The cells were washed once with PBS and the PBS was also collected. Then, cells were removed using $0.1 \%$ trypsin-EDTA and the trypsin digestion was stopped using previously collected media. The cells were then centrifuged at $1000 \mathrm{rpm}$ for $5 \mathrm{~min}$ and the supernatant was aspirated. The cells were resuspended in $4 \mathrm{~mL}$ of PBS and the cells were counted using a Beckman Coulter Multisizer III (17). 
The cells were centrifuged again at $1000 \mathrm{rpm}$ for 5 minutes and the supernatant was aspirated. The cell pellet was resuspended one more time in $4 \mathrm{~mL}$ PBS and centrifuged at $1000 \mathrm{rpm}$ for 5 minutes. The supernatant was aspirated and the cells were placed in $1 \mathrm{~mL}$ of a hypotonic solution of $0.075 \mathrm{M} \mathrm{KCl}$ for 5 minutes followed by $1 \mathrm{~mL}$ of $2 \%$ SDS to lyse the cells for 15 minutes. The cell solution was then sheered through an 18 gauge needle seven times and filtered through a $0.2 \mu \mathrm{m}$ filter. Then $1.5 \mathrm{~mL}$ of the filtered cell solution were diluted in $2.5 \mathrm{~mL} 2 \%$ trace element grade nitric acid. Chromium ion concentrations were measured by AAS using a PinAAcle $900 Z$ Atomic Absorption Spectrometer. Each experiment was repeated at least three times, and each sample was analyzed by AAS in triplicate.

To account for the possibility that undissolved chromium particles may pass through the $0.2 \mu \mathrm{m}$ filter $0 \mathrm{~h}$ treatments were performed for the particulate chromium experiments. The chromium ion concentrations from the $0 \mathrm{~h}$ treatment were subtracted from the $24 \mathrm{~h}$ treatment chromium ion concentrations. For all samples the corrected intracellular chromium ion concentrations were converted from $\mu \mathrm{g} / \mathrm{L}$ to $\mu \mathrm{M}$ by dividing by the volume of the sample, the atomic weight of chromium, the number of cells in the sample, and the average cell volume determined by a Beckman Coulter Multisizer III.

\subsection{Cytotoxicity assay}

Cytotoxicity was determined using a clonogenic assay designed to measure a reduction in plating efficiency in treatment groups that can be compared to the control (Figure 4) (17). Cells were seeded at a density of about $1500 \mathrm{cells} / \mathrm{cm}^{2}$ in 
a 6-well tissue-culture plate, and allowed to grow for $48 \mathrm{~h}$. The cells were then treated for $24 \mathrm{~h}$ with various concentrations of sodium chromate or lead chromate. After the treatment time the media were collected to include any loosely attached mitotic cells, and the cells were rinsed once with PBS. Then, cells were removed from the 6 -well plate using $0.1 \%$ trypsin. Previously collected media was used to stop the enzymatic action of trypsin and the cell solutions were centrifuged at 1000 rpm for 5 minutes. The media were aspirated and the pellet was resuspended in 5 $\mathrm{mL}$ of fresh complete media.

The cells were the counted using a Beckman Coulter Multisizer III and reseeded at colony forming density (1000 cells per dish) with $5 \mathrm{~mL}$ of media in $100-\mathrm{mm}$ tissue-culture dishes pre-coated with attachment factor. The cells were allowed to grow until colonies were visible, approximately 2.5 weeks and were fed with warm, fresh media every 5 days during that time. When colonies had formed they were fixed with $100 \%$ methanol, stained with crystal violet and counted. There were four dishes per treatment group, and each experiment was repeated at least three

times. The results are expressed as relative survival derived from the number of colonies within a treatment group divided by the number of colonies in the negative control.

\subsection{Clastogenicity assay}

Clastogenicity was measured using a chromosome aberration assay (17). Cells were seeded at a density of 700,000 cells in 100-mm tissue-culture dishes and 
allowed to grow for $48 \mathrm{~h}$. The cultures were then treated with various concentrations of sodium chromate, lead chromate, or zinc chromate for $24 \mathrm{~h}$ or

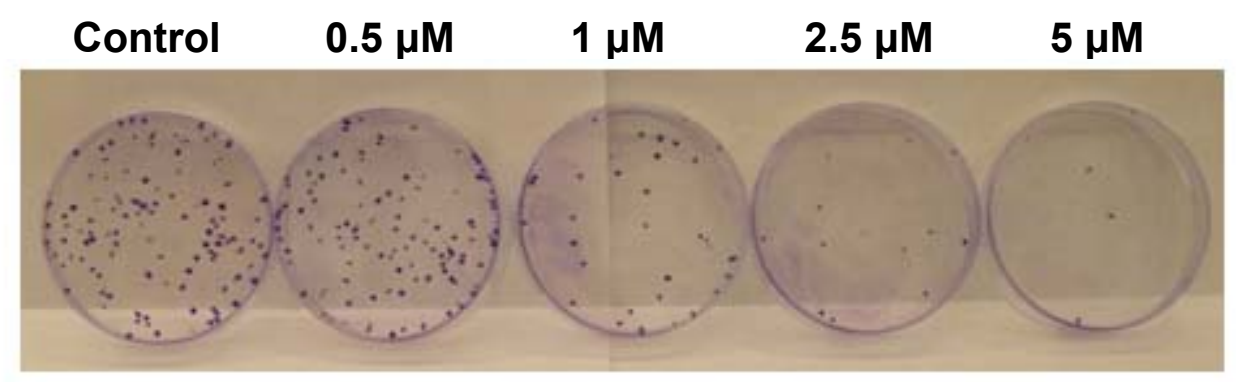

\section{Figure 4. Cytotoxicity Assay}

This figure shows representative images of stained cytotoxicity dishes where colonies are visible. The dish on the left is the control and each dish to the right was treated with increasing concentrations of sodium chromate. With increasing concentrations of sodium chromate there are fewer colonies indicating cytotoxicity.

$120 \mathrm{~h}$ exposure periods. Five hours (sea turtle cells) or one hour (NHLF cells) before the end of the treatment time, $0.1 \mu \mathrm{g} / \mathrm{ml}$ demecolcine was added to arrest the cells in metaphase.

After the exposure time the media was collected from each dish to include any loosely adherent mitotic cells, and the cells were rinsed once with PBS. Then the cells were removed from the dishes using $0.1 \%$ trypsin. Previously collected media was used to stop the enzymatic action of trypsin and the cell solutions were centrifuged at $1000 \mathrm{rpm}$ for 5 minutes. The supernatant was aspirated and the pellet was resuspended in $10 \mathrm{~mL}$ of $0.075 \mathrm{M}$ potassium chloride hypotonic solution for 17 minutes in order to swell the cells. Then $1 \mathrm{~mL}$ of methanol: acetic acid (3:1) fixative was added to the hypotonic cell solution to prepare the cells for fixing. The cells were the centrifuged again at $1000 \mathrm{rpm}$ for 5 minutes and the supernatant 
was aspirated. Then, $10 \mathrm{~mL}$ of methanol: acetic acid (3:1) fixative was slowly added to the resuspended cells. The cells were maintained in the fixative at $4{ }^{\circ} \mathrm{C}$ for at least 20 minutes, then the fixative was changed twice. Cells were then dropped on clean wet slides and stained using a 5\% Geimsa stain in Gurr's buffer.

\subsection{Chromosome scoring criteria}

One hundred individual metaphases per treatment concentration were analyzed (50 per scorer) in each experiment and each experiment was repeated at least three times (18). Clastogenesis was measured based on the number and frequency of chromosome aberrations. The various types of aberrations were pooled together in order to determine the total amount of damage in 100 metaphases. Additionally, the percent of metaphases with any type of damage was also calculated. Specifically, metaphases were analyzed for various types of chromosome damage including chromatid lesions (gaps and breaks), isochromatid lesions (gaps and breaks), chromatid exchanges, dicentric chromosomes, ring structures, double minutes, acentric fragments, chromatid exchanges, and fragmented chromosomes (Figure 5). Metaphases were also analyzed for aneuploidy and metaphase damage including centromere spreading, endoreduplication, hypercondensation, premature centromere division, and premature anaphase (Figure 6). 


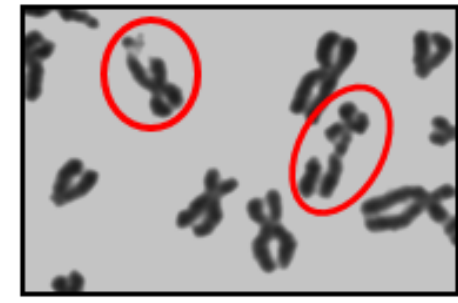

Chromatid Lesion

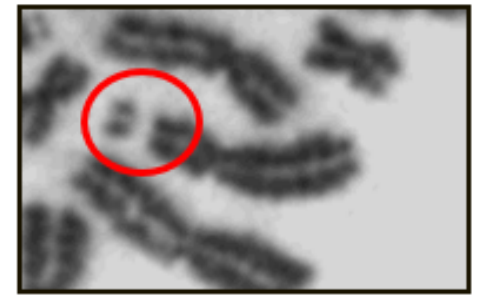

Isochromatid Lesion

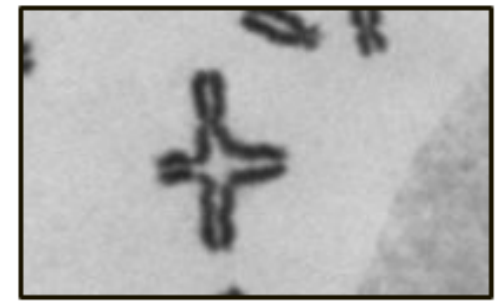

Chromatid Exchange

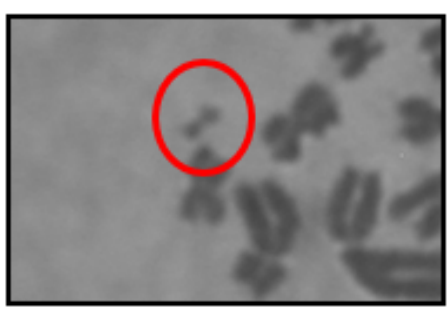

Double Minutes

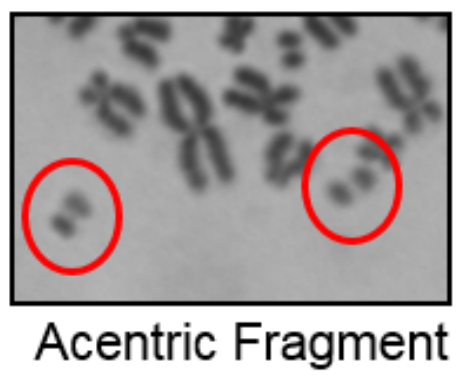

\section{Figure 5. Types of Chromosome Damage}

This figure illustrates several types of damage that are scored in the genotoxicity assay. For example, chromatid lesions occur where there is a break in one arm of the chromosome whereas an isochromatic lesion occurs where there is a break in both chromosome arms.

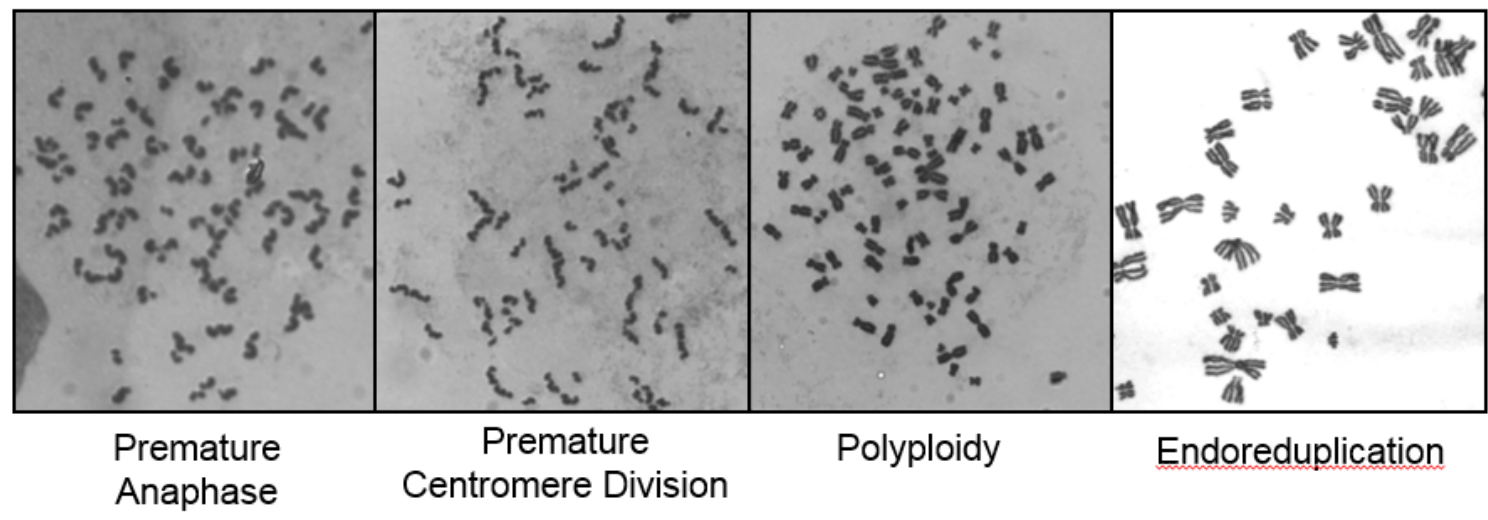

Figure 6. Types of Metaphase Damage

This figure shows representative images of the types of metaphase damage screened for in the genotoxicity assay including premature anaphase, premature centromere division, polyploidy, and endoreduplication. 


\subsection{Statistics}

Student's t-tests were conducted to determine statistical significance between data points. Results are presented as the mean \pm standard error of the mean. Statistical significance was determined to be a $p$ value less than 0.05 . 


\section{CHAPTER 3: RESULTS - A COMPARISON OF THE CYTOTOXIC AND GENOTOXIC EFFECTS OF CHROMATE COMPOUNDS IN LEATHERBACK SEA TURTLES}

3.1 Particulate and Soluble Hexavalent Chromium Compounds are Cytotoxic to Leatherback Sea Turtle Lung Cells

Cytotoxicity was measured using a clonogenic survival assay to determine the ability for cells to proliferate after exposure to chemicals. Exposure to particulate or soluble chromate induced a concentration-dependent decrease in relative survival in leatherback sea turtle lung cells after $24 \mathrm{~h}$ exposure (Figure 7A, 7B, and 7C). Soluble sodium chromate exposures of $0.5,1,2.5,5$, and $10 \mu \mathrm{M}$ reduced relative survival to $86.6,62,40.3,17.4$, and $4.4 \%$, respectively. Particulate lead chromate exposures of $0.1,0.5,1,5$, and $10 \mu \mathrm{g} / \mathrm{cm}^{2}$ reduced relative survival to $87.5,66.2,51.2,18$, and $6.3 \%$, respectively. Particulate zinc chromate exposures

of $0.1,0.15,0.2,0.3$, and $0.4 \mu \mathrm{g} / \mathrm{cm}^{2}$ reduced relative survival to $68.8,56.4,42.9$, 33.2 , and 17.6 , respectively. 

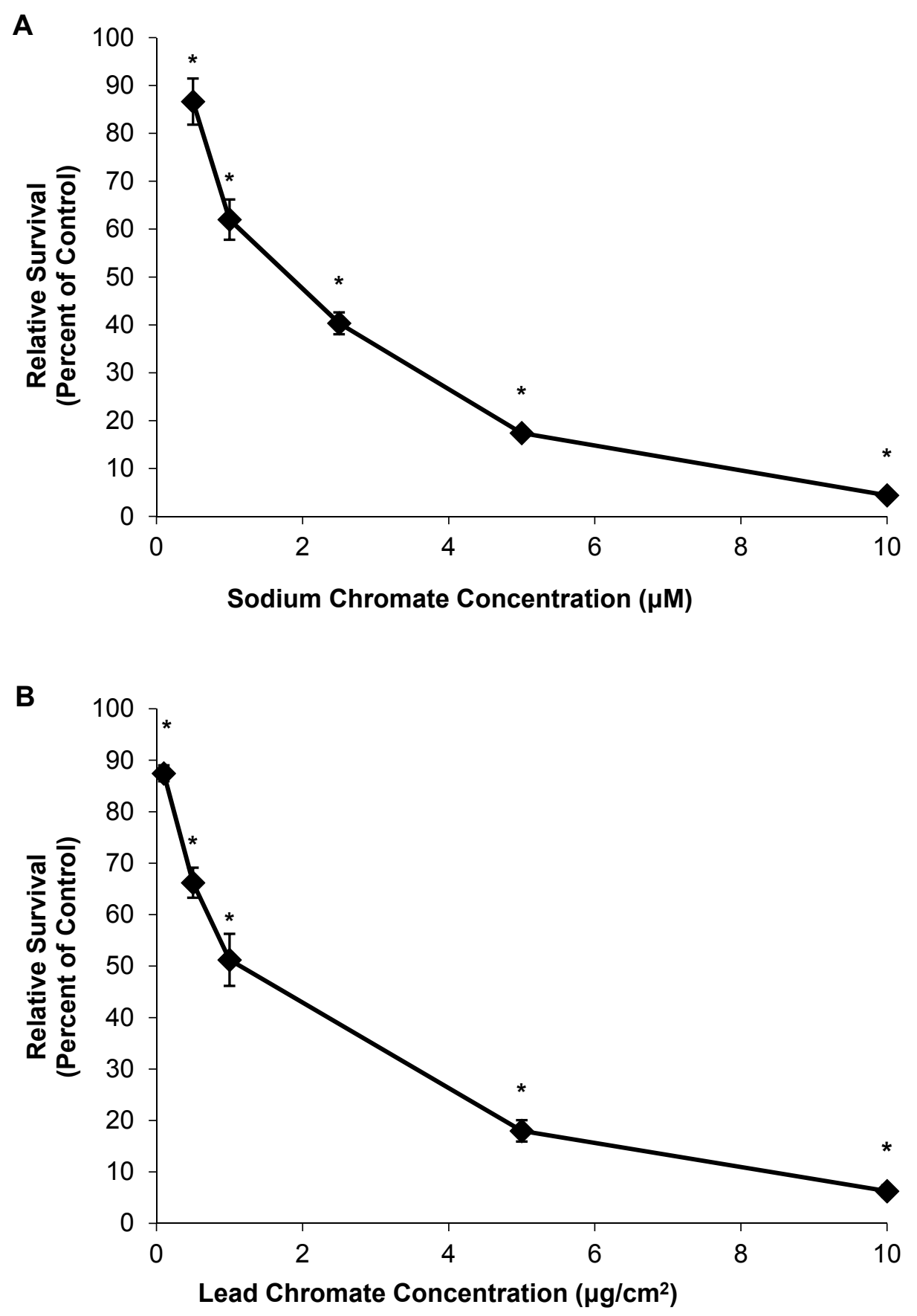


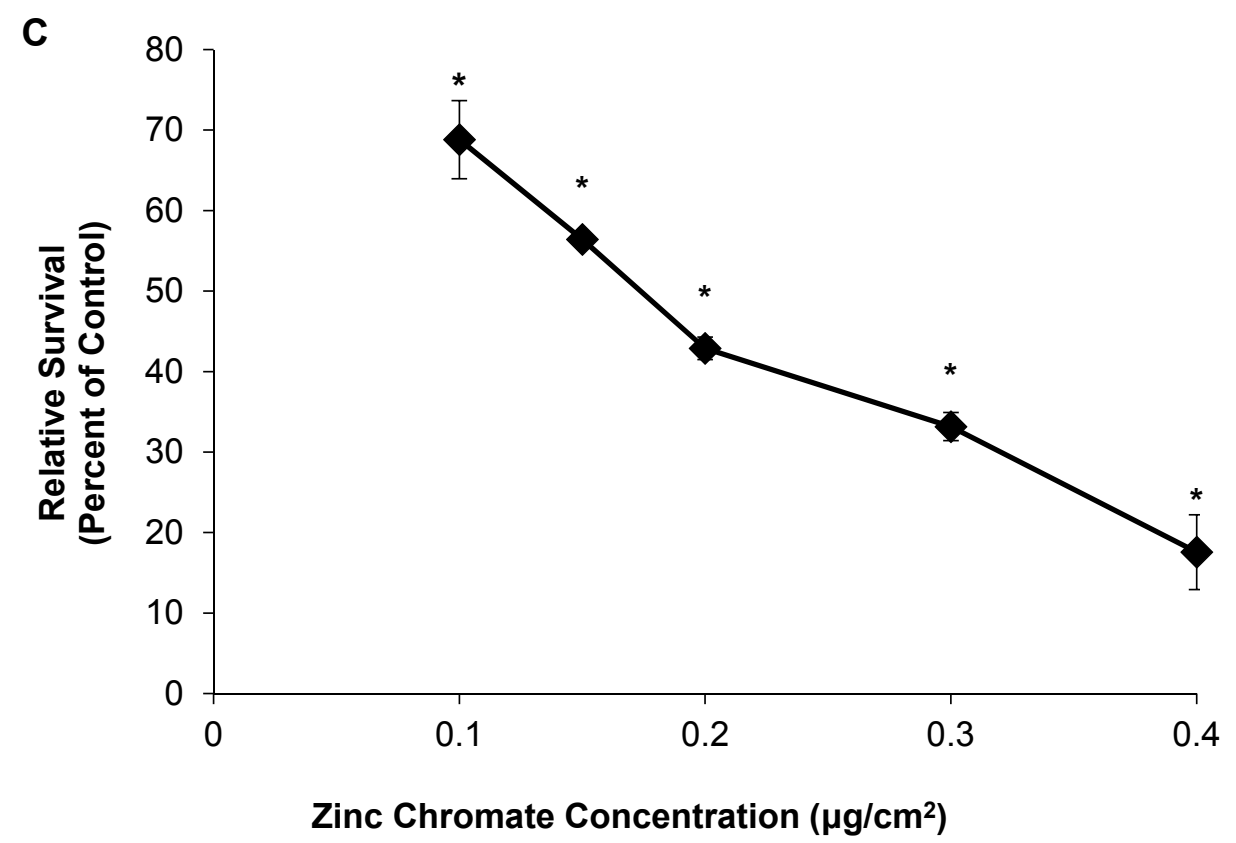

Figure 7: Particulate and Soluble Chromate are Cytotoxic to Leatherback Sea Turtle Lung Cells

This figure shows $24 \mathrm{~h}$ exposure to particulate or soluble chromate reduced relative survival in a concentration-dependent manner. Data represent an average of at least three independent experiments \pm standard error of the mean. *Statistically significant compared to control $(p<0.05)$. a) Sodium chromate b) Lead chromate c) Zinc chromate.

3.2 Particulate and Soluble Hexavalent Chromium are Genotoxic to Leatherback Sea Turtle Lung Cells

Next the genotoxicity of particulate and soluble chromate compounds was measured in leatherback sea turtle lung cells using a chromosome aberration assay. Both particulate and soluble chromate induced a concentration-dependent increase in genotoxicity in leatherback sea turtle lung cells (Figure $8 \mathrm{~A}, 8 \mathrm{~B}$, and $8 \mathrm{C})$. Treatment with $24 \mathrm{~h}$ exposure to $0,0.5,1,2.5$, and $5 \mu \mathrm{M}$ soluble sodium chromate resulted in $9,15,23.3,31$, and $35.3 \%$ of metaphases with damage and $9.3,17.3,29.7,40.7$, and 50.7 total damage in 100 metaphases. Similarly, 0, 0.1, 
$0.5,1$, and $5 \mu \mathrm{g} / \mathrm{cm}^{2}$ particulate lead chromate for $24 \mathrm{~h}$ resulted in $10.3,8,16.7$, 23.7 and $31.3 \%$ of metaphases with damage and $14.3,9.7,21,28$, and 43.7 total damage in 100 metaphases. Finally, treatment with $24 \mathrm{~h}$ exposure to $0.1,0.15$, $0.2,0.3$, and $0.4 \mu \mathrm{g} / \mathrm{cm}^{2}$ particulate zinc chromate resulted in $8,19.3,23.3,27.3$, 34.7 , and $38.7 \%$ of metaphases with damage and $11.3,24.7,32,33.3,48$, and 51.3 total damage in 100 metaphases. Treatment with the highest concentration for lead chromate and sodium chromate $\left(10 \mu \mathrm{g} / \mathrm{cm}^{2}\right.$ and $10 \mu \mathrm{M}$, respectively) tested in our cytotoxicity assays resulted in no metaphases in the genotoxicity assays indicating cell cycle arrest or failure to enter mitosis.

\section{Figure 8}

A

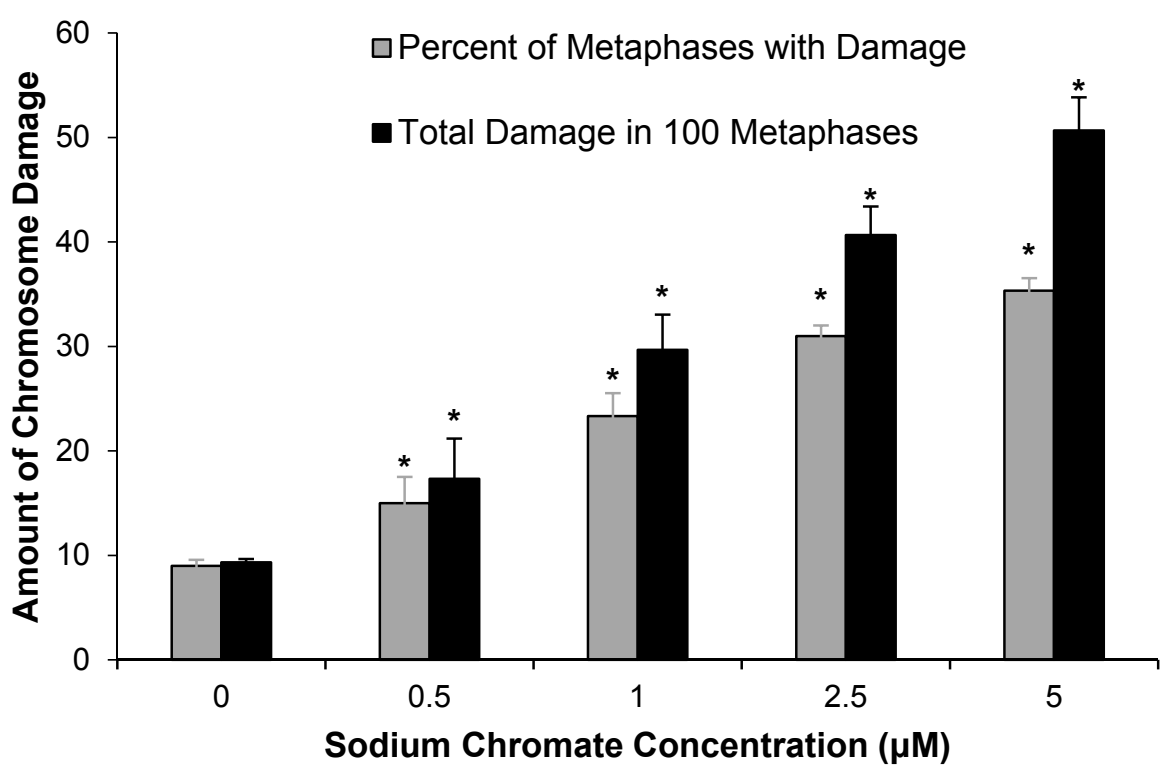



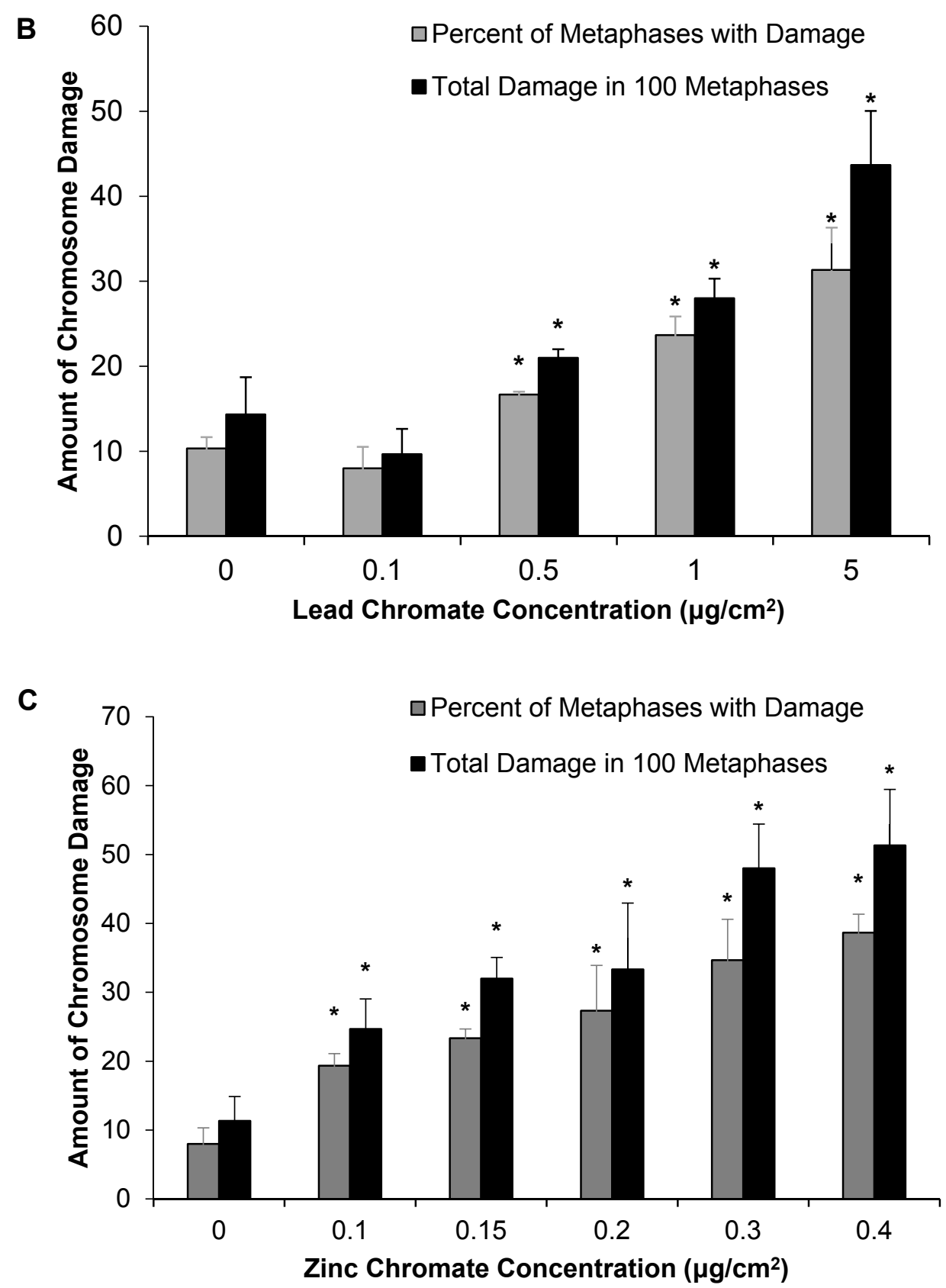

Figure 8: Particulate and Soluble Chromate are Genotoxic to Leatherback Sea Turtle Lung Cells

This figure shows after $24 \mathrm{~h}$ exposure particulate and soluble chromate induces a concentration-dependent increase in chromosome damage. No metaphases were observed at the highest concentration tested for particulate chromate $\left(10 \mu \mathrm{g} / \mathrm{cm}^{2}\right)$ or soluble chromate $(10 \mu \mathrm{M})$. Data represent an average of three independent experiments \pm standard error of the mean. *Statistically significant compared to control $(p<0.05)$. a) Sodium chromate. b) Lead chromate c) Zinc chromate. 

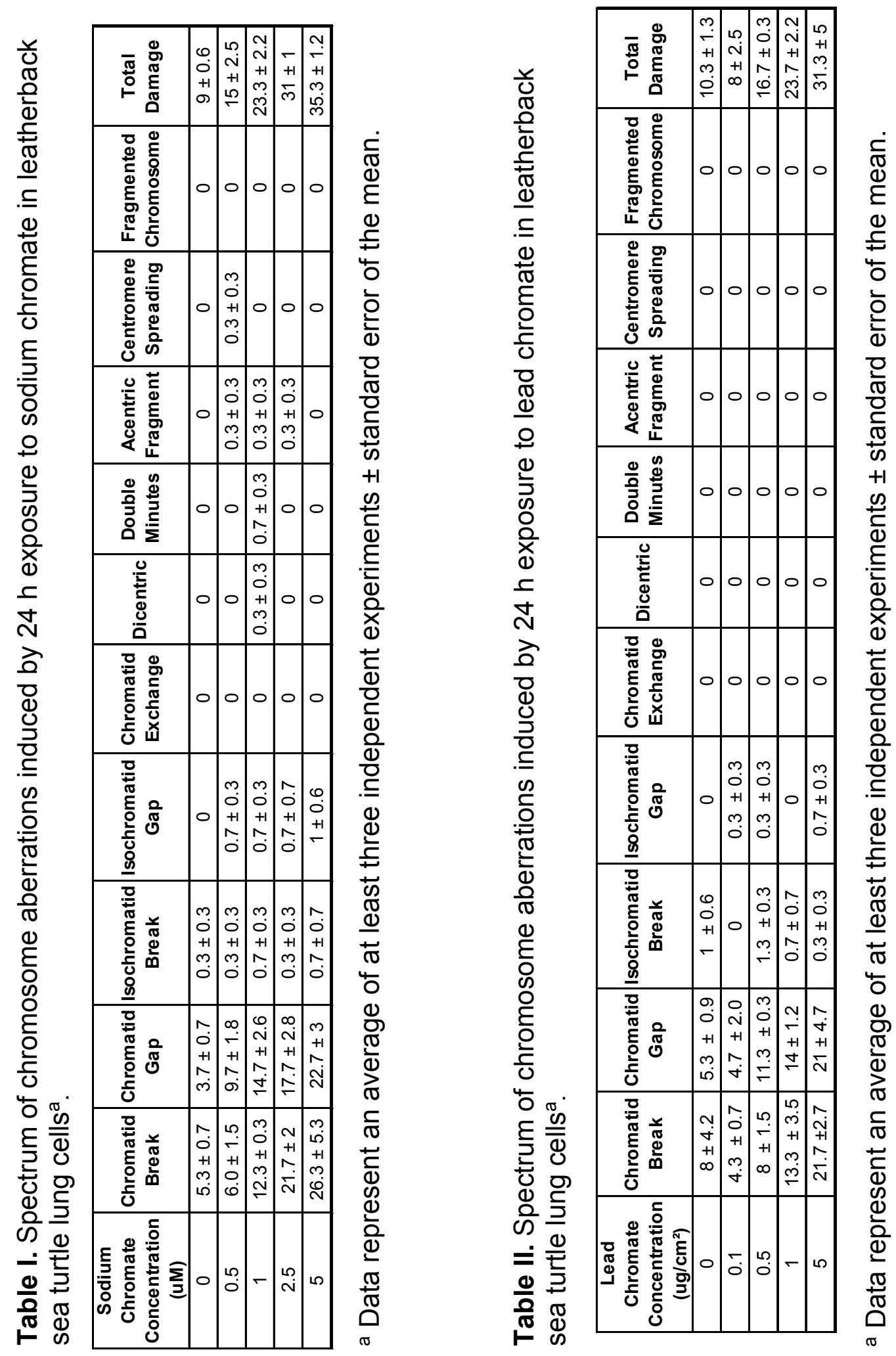


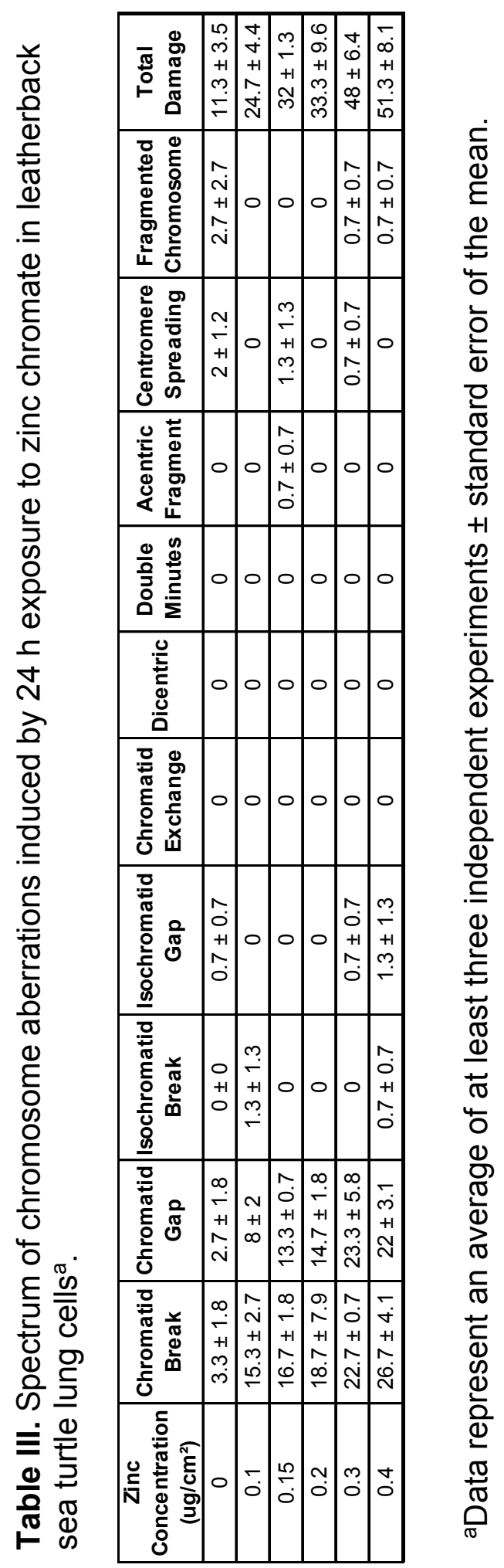


Additionally, the total amount of damage in 100 metaphases was increased compared to the percent of metaphases with damage following both particulate and soluble chromate exposures. This outcome reflects that some cells contained more than one event of damage e.g. two chromatid breaks. A majority of the damage observed in the leatherback sea turtle lung cells following soluble or particulate chromate exposures were chromatid gaps or chromatid breaks (Table I, II, and III). Other more complex types of damage such as centromere spreading or dicentric chromosomes were either not observed or occurred at a very low frequency in the analysis, however there were slightly more complex types of damage in zinc chromate treated cells than the sodium chromate or lead chromate treated cells.

\subsection{Intracellular Chromium Ion Concentrations Increase Following Particulate or} Soluble Hexavalent Chromium Exposure

Cells use different mechanisms to import metals depending on the solubility of the metal and valence states. Therefore different concentrations of metal ions accumulate in cells following exposures. Additionally, soluble and particulate chromate differ in their units of measurement i.e. $\mu \mathrm{M} v \mathrm{vs}, \mu \mathrm{g} / \mathrm{cm}^{2}$, respectively. Intracellular levels of chromium following $24 \mathrm{~h}$ exposure to either soluble or particulate chromate in leatherback sea turtle lung cells were measured to investigate the possibility for differing intracellular accumulation. Intracellular chromium ion concentrations increased in a concentration-dependent manner after soluble or particulate chromate exposure in leatherback sea turtle lung cells (Figure 9A, 9B, and 9C). For example, $24 \mathrm{~h}$ exposure to $0,0.5,1,2.5,5$, and 10 
$\mu \mathrm{M}$ soluble sodium chromate intracellular chromium ion concentrations were 12 , $75,142,471,868$, and $1229 \mu \mathrm{M}$, respectively. Similarly, $0,0.1,0.5,1,5$, and 10 $\mu \mathrm{g} / \mathrm{cm}^{2}$ particulate lead chromate resulted in intracellular chromium ion concentrations of $0,1,210,399,763$, and $1076 \mu \mathrm{M}$, respectively. Finally, after 24 $\mathrm{h}$ exposure to $0.1,0.15,0.2,0.3$, and $0.4 \mu \mathrm{g} / \mathrm{cm}^{2}$ particulate zinc chromate intracellular chromium ion concentrations were slightly lower than the other two chromate compounds at $0,84,150,207,262$, and $381 \mu \mathrm{M}$, respectively.

3.4 Chromate Compounds Induce Similar levels of Cytotoxicity and Genotoxicity Based on Intracellular Chromium Concentrations

In order to compare particulate and soluble chromate exposures directly the cytotoxicity of particulate and soluble chromate were evaluated using the intracellular chromium ion concentrations determined by AAS. Based on these intracellular chromium ion concentrations soluble sodium chromate and particulate lead chromate induce similar levels of cytotoxicity (Figure 10A). However, cells treated with zinc chromate had similar levels of cytotoxicity but at much lower intracellular chromium ion concentrations. For example, for the second highest concentration of lead chromate tested, an intracellular chromium ion concentration of $763 \mu \mathrm{M}$ reduced relative survival to $18 \%$ while an intracellular chromium ion concentration of $868 \mu \mathrm{M}$ following the second highest concentration of sodium chromate reduced relative survival to $17.4 \%$, and the highest dose of zinc chromate with an intracellular chromium ion concentration of $381 \mu \mathrm{M}$ reduced relative survival to $17.6 \%$. Therefore, zinc chromate induces similar levels of cytotoxicity at half the intracellular chromium ion concentration required by sodium or lead chromate at higher concentrations. 

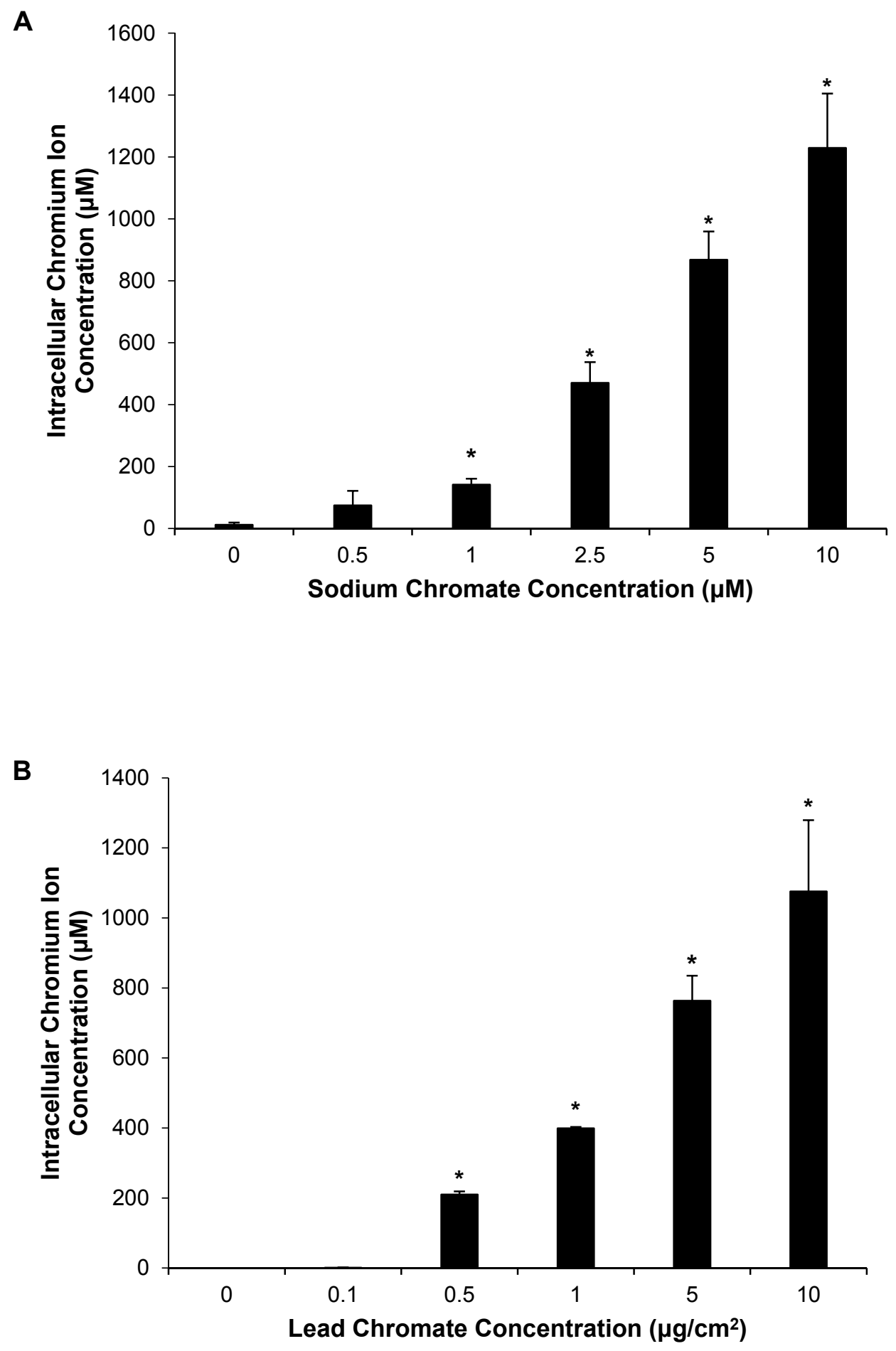


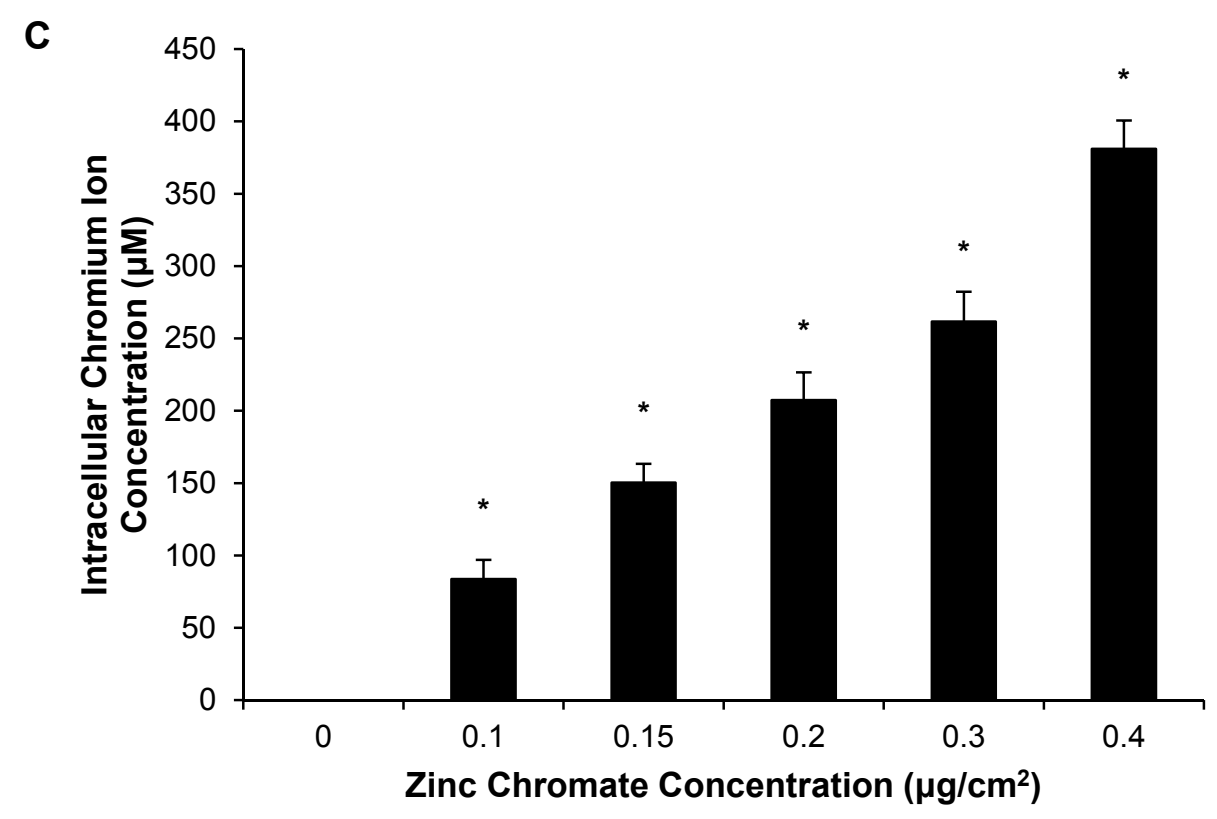

Figure 9. Intracellular Chromium Ion Concentrations Increase with Increasing Particulate and Soluble Chromate Treatment.

This figure shows that with increasing particulate and soluble chromate treatments, intracellular chromium ion concentrations increase in a concentration-dependent manner. Data represent an average of at least three independent experiments \pm standard error of the mean. * Statistically significant compared to control $(p<0.05)$. a) Sodium chromate. b) Lead chromate c) Zinc chromate.

The genotoxicity of soluble and particulate $\mathrm{Cr}(\mathrm{VI})$ was measured using the intracellular chromium ion concentrations from the metal ion uptake assays. Lead chromate was slightly less genotoxic compared to sodium chromate at similar intracellular chromium ion concentrations (Figure 10B). For example, an intracellular chromium ion concentration of $399 \mu \mathrm{M}$ following $24 \mathrm{~h}$ exposure to particulate chromate resulted in 23.7 percent of metaphases with damage while an intracellular chromium ion concentration of $471 \mu \mathrm{M}$ following soluble chromate exposure resulted in 23.3 percent of metaphases with damage. Zinc chromate 
induced similar levels of genotoxicity as lead chromate and sodium chromate at slightly lower intracellular chromium ion concentrations. For example, an intracellular chromium ion concentration of $262 \mu \mathrm{M}$ following zinc chromate exposure induced 34.7 percent of metaphases with damage.
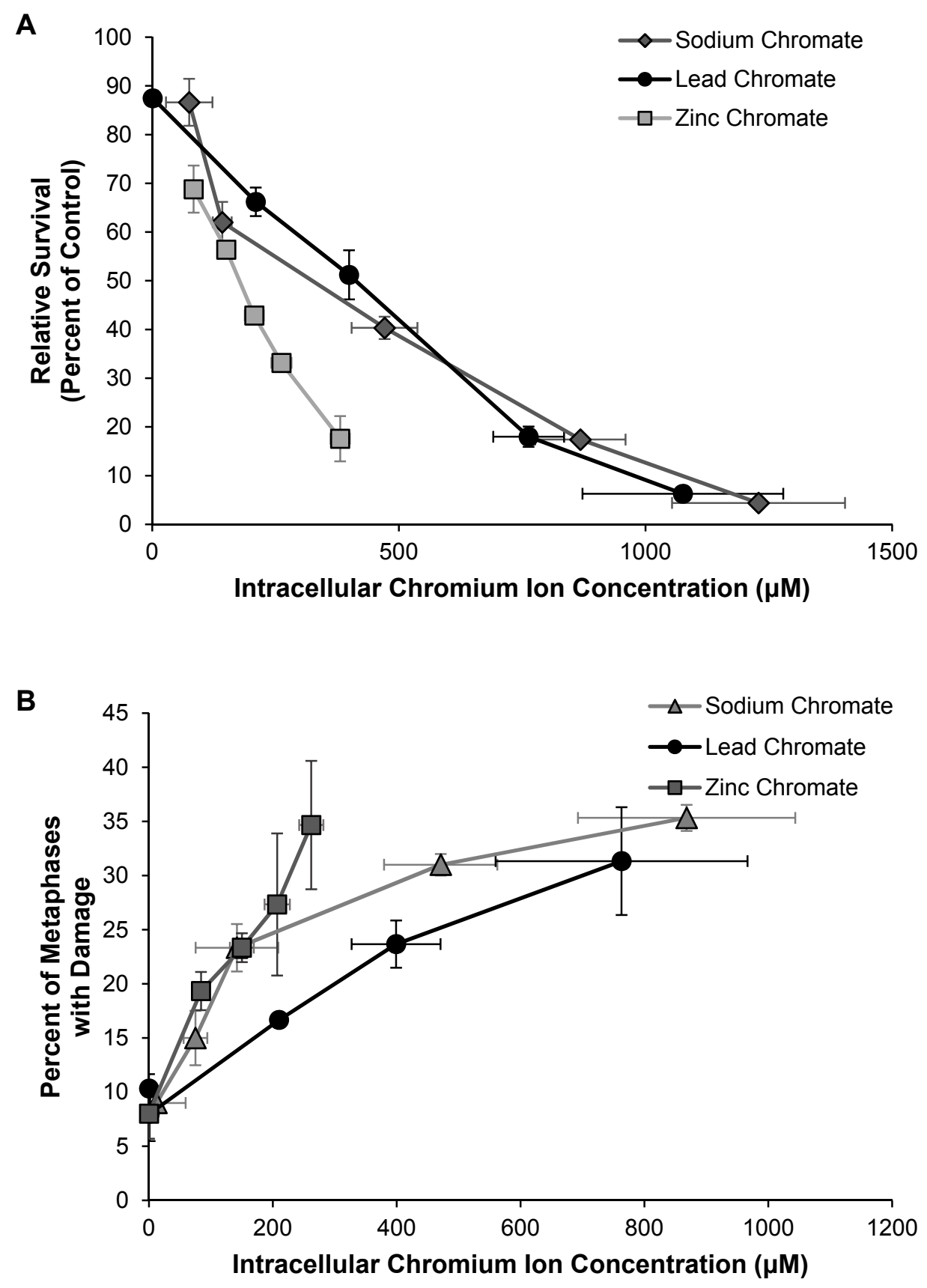
Figure 10: Particulate and Soluble Chromium Induce Varying Levels of Cytotoxicity and Genotoxicity in Leatherback Sea Turtle Lung Cells

This figure shows that at similar levels of intracellular chromium ion concentrations particulate and soluble chromate induce a similar frequency of cells with damage and similar levels of total chromosome damage. a) Relative survival. b) Percent of metaphases with damage. Data represent an average of at least three experiments \pm standard error of the mean. 


\section{CHAPTER 4: RESULTS - A COMPARISON OF THE CYTOTOXICITY AND GENOTOXICITY OF PARTICULATE Cr(VI) IN HUMAN AND LEATHERBACK SEA TURTLE LUNG CELLS}

In this data set, the effects of particulate zinc chromate in leatherback sea turtle and human lung cells were compared directly. The two species were treated with the same concentrations of zinc chromate and assessed using the same parameters. Additionally, both acute, $24 \mathrm{~h}$, and prolonged, $120 \mathrm{~h}$, exposure periods were included in order to assess how these cell types may be affected temporally. This approach is especially important considering that particulate chromate exposures tend to be long term events.

4.1 Particulate Hexavalent Chromium is Similarly Cytotoxic to Leatherback Sea Turtle and Human Lung Cells

First, the cytotoxicity of zinc chromate was assessed using the clonogenic survival assay based on treatment concentrations. Exposure to zinc chromate induced a similar concentration-dependent decrease in relative survival in leatherback sea turtle and human lung cells after 24 and $120 \mathrm{~h}$ exposure (Figure 11A and 11B). Exposures of $0.1,0.15,0.2,0.3$, and $0.4 \mu \mathrm{g} / \mathrm{cm}^{2}$ zinc chromate for $24 \mathrm{~h}$ reduced relative survival to $68.6,56.4,42.9,33.2$, and $17.6 \%$, respectively in the leatherback cells and $93,87.9,68.9,41.4$, and $23.8 \%$ respectively in the human cells. After $120 \mathrm{~h}$ exposure of $0.1,0.15,0.2,0.3$, and $0.4 \mu \mathrm{g} / \mathrm{cm}^{2}$ zinc chromate 
relative survival was reduced to $81.1,68.3,41,15.5$, and $3.7 \%$ respectively in leatherback cells and $82.5,48.6,47.4,31.8$, and 19.3 respectively in the human cells.

\section{Figure 11}

A

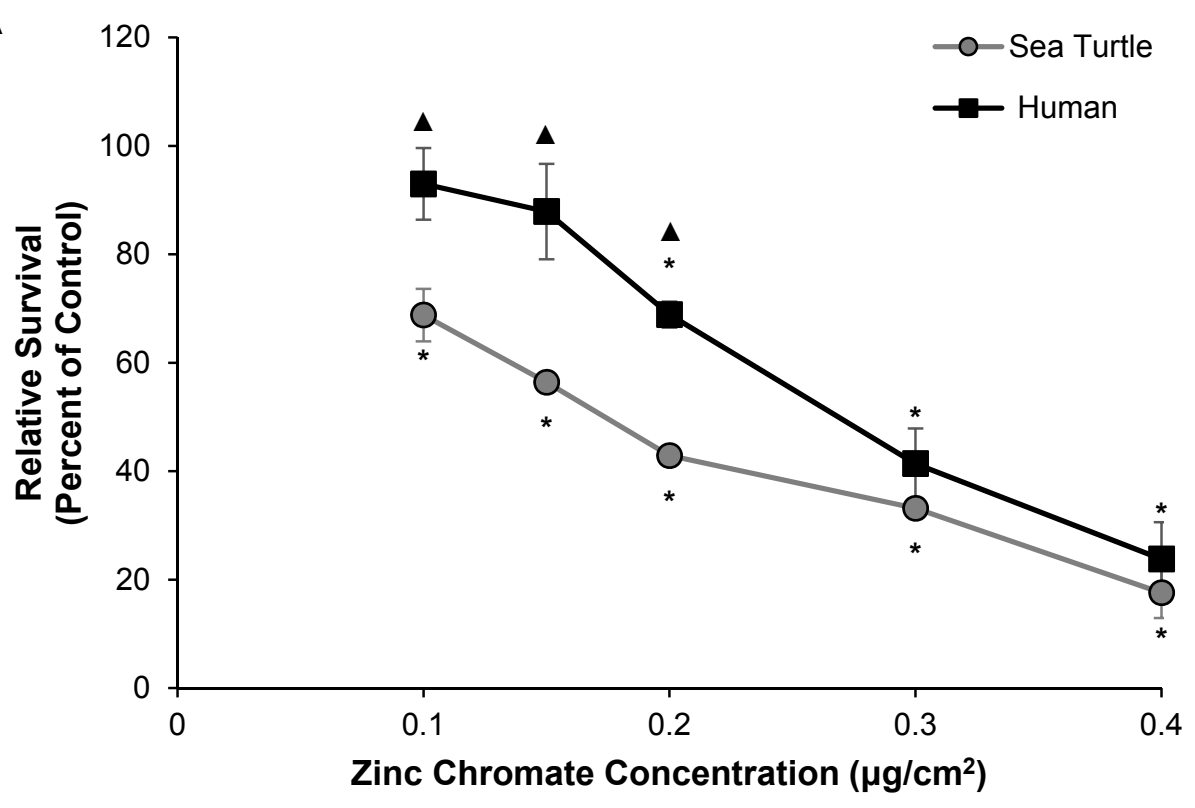

B

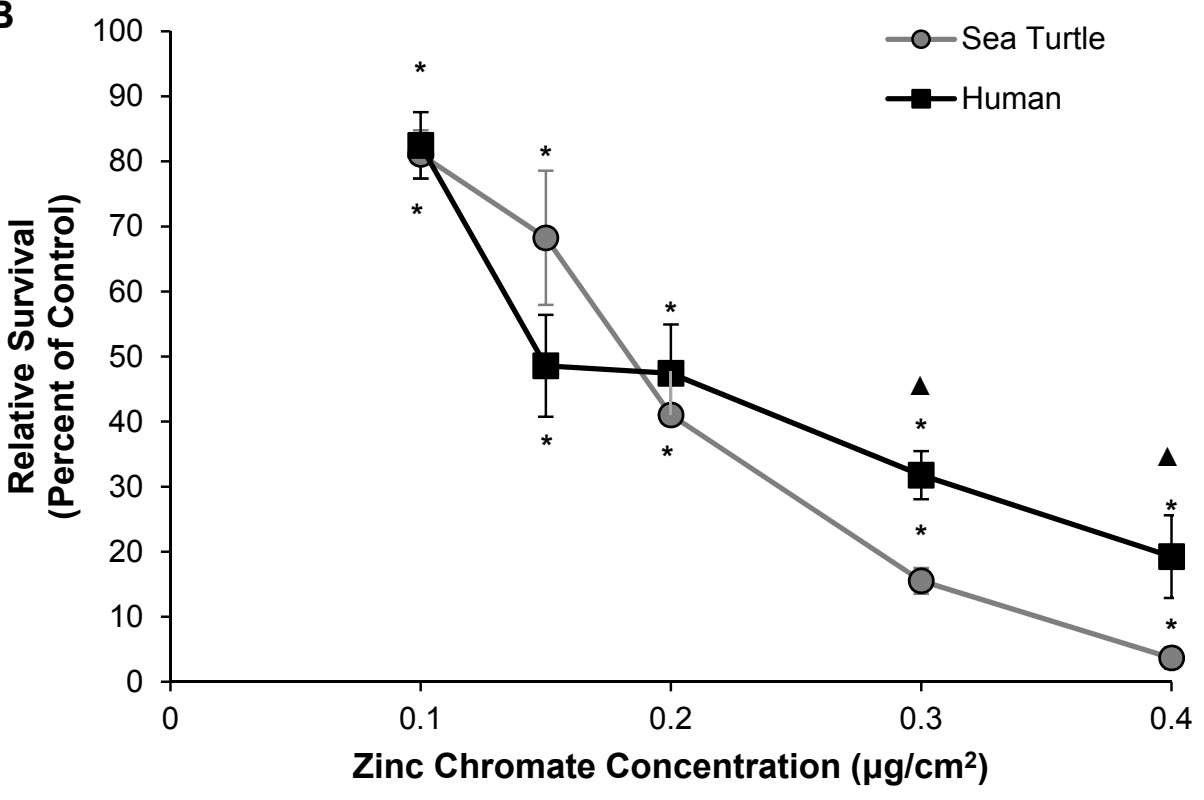


Figure 11: Particulate Chromate is Cytotoxic to Leatherback Sea Turtle and Human Lung Cells

This figure shows 24 or $120 \mathrm{~h}$ exposure to particulate zinc chromate reduced relative survival in a concentration-dependent manner in leatherback sea turtle and human lung cells. Data represent an average of at least three independent experiments \pm standard error of the mean. *Statistically significant compared to control $(p<0.05)$. ${ }^{\Delta}$ Statistically significant between sea turtle and human $(p<0.05$. a) $24 \mathrm{~h} \mathrm{b)} 120 \mathrm{~h}$.

4.2 Exposure Time of Particulate Chromate has Different Effects in Leatherback Sea Turtle and Human Lung Cells

Next the genotoxicity of zinc chromate in leatherback sea turtle and human lung cells was compared using the chromosome aberration assay. Zinc chromate induced a concentration-dependent increase in genotoxicity in both leatherback sea turtle and human lung cells after 24 and $120 \mathrm{~h}$ exposure (Figure 12A and 12B). Treatment with $24 \mathrm{~h}$ exposure to $0.1,0.15,0.2,0.3$, and $0.4 \mu \mathrm{g} / \mathrm{cm}^{2}$ zinc chromate resulted in $19.3,23.3,27.3,34.7$, and $38.7 \%$ of metaphases with damage in leatherback cells. After $24 \mathrm{~h}$ exposure to $0.1,0.15,0.2$, and $0.3 \mu \mathrm{g} / \mathrm{cm}^{2}$ zinc chromate in human cells the percent of metaphases with damage were $29.3,35$, 38.7 , and 45.7 , respectively.

After $120 \mathrm{~h}$ exposure to $0.1,0.15,0.2$ and $0.3 \mu \mathrm{g} / \mathrm{cm}^{2}$ zinc chromate there were $28,31.3,39.3$, and $48 \%$ of metaphases with damage in leatherback lung cells, respectively. Treatment with $0.1,0.15,0.2 \mu \mathrm{g} / \mathrm{cm}^{2}$ zinc chromate in human lung cells resulted in $16,19.3$, and $28 \%$ of metaphases with damage, respectively. There were no metaphases after $24 \mathrm{~h}$ exposure to zinc chromate at the highest dose of $0.4 \mu \mathrm{g} / \mathrm{cm}^{2}$ in human lung cells, and after $120 \mathrm{~h}$ exposure there were no metaphases at this concentration in either cell line. Additionally, after $120 \mathrm{~h}$ 
exposure to zinc chromate there were no metaphases in human cells at the 0.3 $\mu \mathrm{g} / \mathrm{cm}^{2}$ concentration.
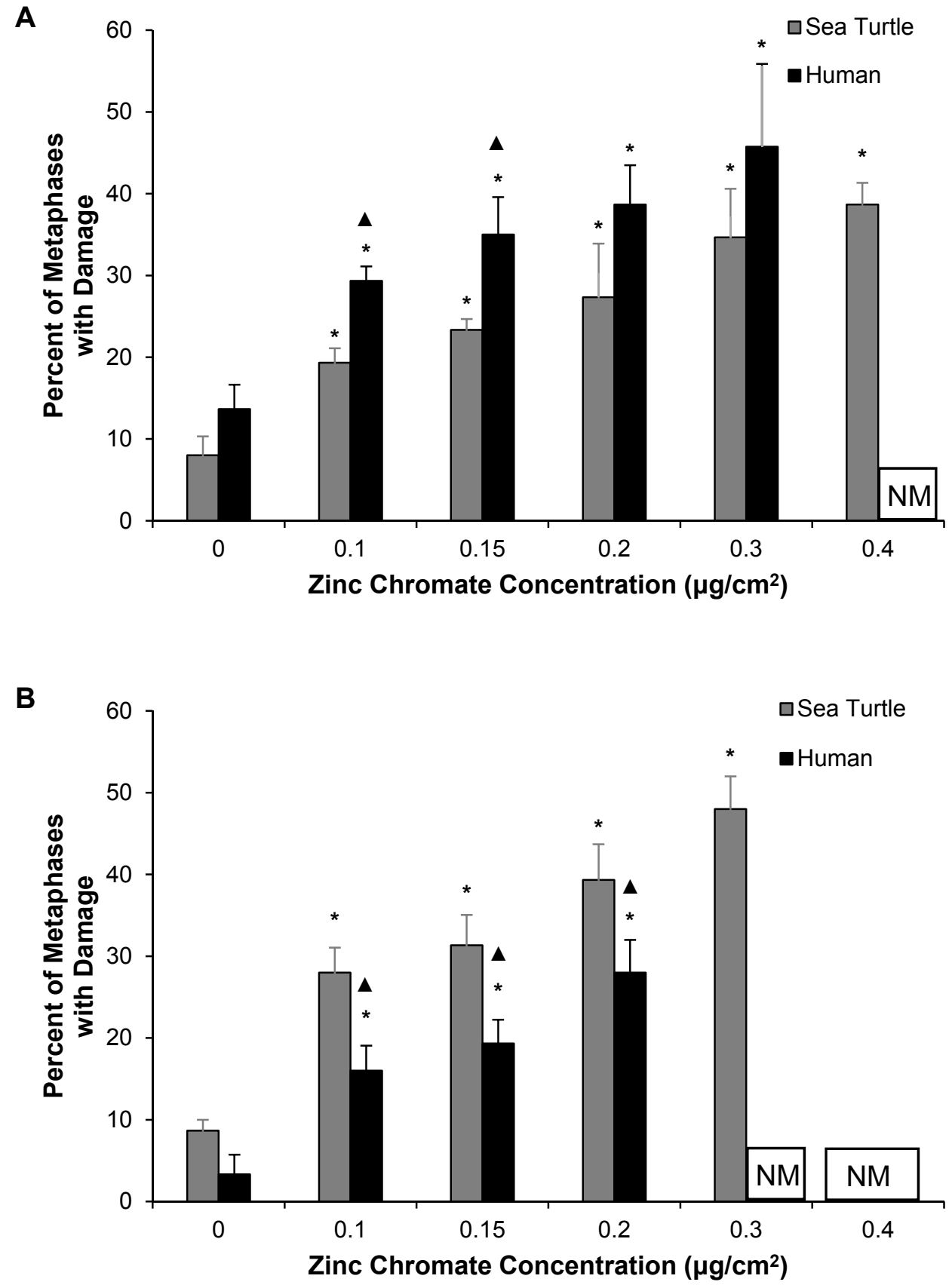

Figure 12. Particulate Chromate Induces Genotoxicity in Leatherback Sea Turtle and Human Lung Cells

This figure shows 24 or $120 \mathrm{~h}$ exposure to particulate zinc chromate increases chromosome damage in a concentration-dependent manner in leatherback sea 
turtle and human lung cells. At the highest dose after $24 \mathrm{~h}$ exposure and the highest two doses after $120 \mathrm{~h}$ exposure no metaphases (NM) were observed in human lung cells. Similarly, there were no metaphases at the highest dose after $120 \mathrm{~h}$ exposure in leatherback sea turtle lung cells. Data represent an average of at least three independent experiments \pm standard error of the mean. *Statistically significant compared to control $(p<0.05)$. ${ }^{\wedge}$ Statistically significant between sea turtle and human ( $p<0.05$. a) $24 \mathrm{~h}$ b) $120 \mathrm{~h}$.

Based on these data, after $24 \mathrm{~h}$ exposure to zinc chromate human cells accumulate more damage and undergo cell cycle arrest at the highest concentration while the leatherback cells continue to accumulate damage. After $120 \mathrm{~h}$ exposure leatherback cells accumulate more damage than human cells but do not undergo cell cycle arrest at levels of damage that this is seen in the human cells. Additionally, a majority of the damage observed following 24 or $120 \mathrm{~h}$ zinc chromate exposure in leatherback sea turtle and human cells were chromatid gaps or chromatid breaks (Tables III, IV, V, and VI). More complex types of chromosome damage were observed at low frequencies in the leatherback sea turtle cells, but these were slightly increased in the human cells. Finally, there appears to be no difference in the types of damage observed between the 24 and $120 \mathrm{~h}$ exposure treatments. 

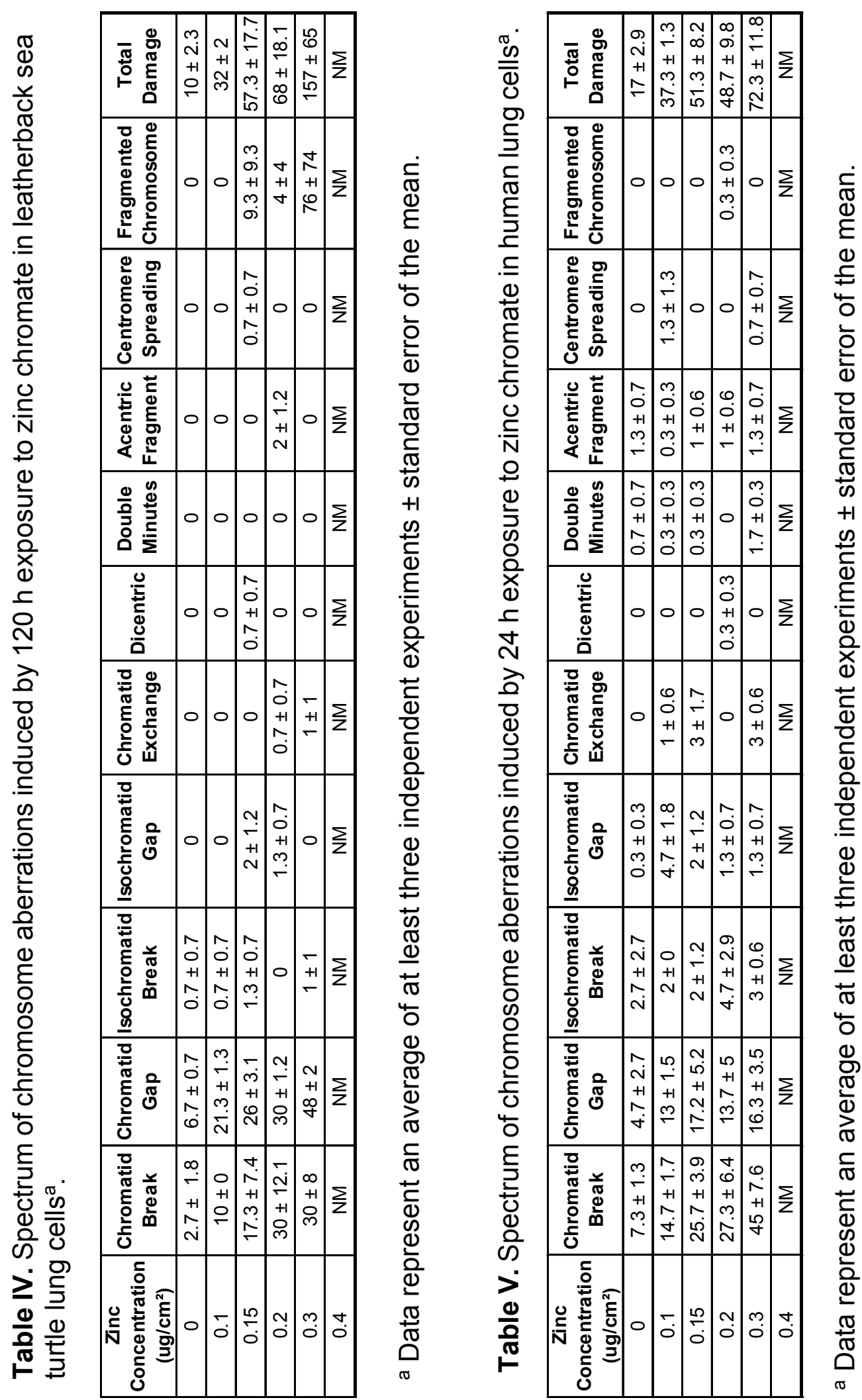


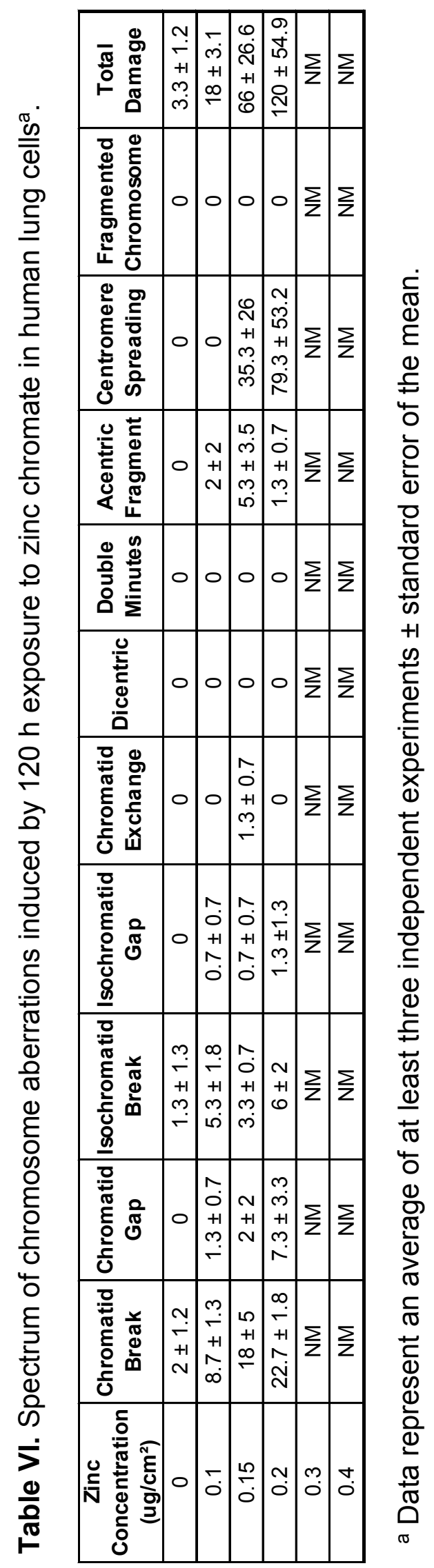


4.3 Intracellular Chromium Ion Concentrations are Similar in Leatherback Sea Turtle and Human Lung Cells Following Particulate Hexavalent Chromium Exposure

Intracellular chromium ion concentrations increased in a concentration-dependent manner after 24 or $120 \mathrm{~h}$ zinc chromate exposure in leatherback sea turtle and human lung cells (Figure 13A and 13B). After $24 \mathrm{~h}$ exposure to $0,0.1,0.15,0.2$, 0.3 , and $0.4 \mu \mathrm{g} / \mathrm{cm}^{2}$ zinc chromate intracellular chromium ion concentrations were $0,84,150,207,262$, and $381 \mu \mathrm{M}$, respectively in leatherback sea turtle cells and $0,60,108,107,280$, and $236 \mu \mathrm{M}$ in human lung cells, respectively. After $120 \mathrm{~h}$ zinc chromate exposure the levels of intracellular $\mathrm{Cr}$ were increased compared to the $24 \mathrm{~h}$ exposure experiments for both cell lines. For example, $0,0.1,0.15,0.2$, 0.3 , and $0.4 \mu \mathrm{g} / \mathrm{cm}^{2}$ zinc chromate resulted in intracellular chromium ion concentrations of $0,171,281,360,706$, and $1035 \mu \mathrm{M}$, respectively while in human lung cells the intracellular chromium ion concentrations were $0,33,77,154,482$, and $502 \mu \mathrm{M}$. The $120 \mathrm{~h}$ human intracellular chromium levels are the result of two independent experiments rather than three due to machine malfunction. Additionally, the leatherback sea turtle cells contained higher levels of chromium after the $120 \mathrm{~h}$ exposure than human cells especially at higher concentrations. 

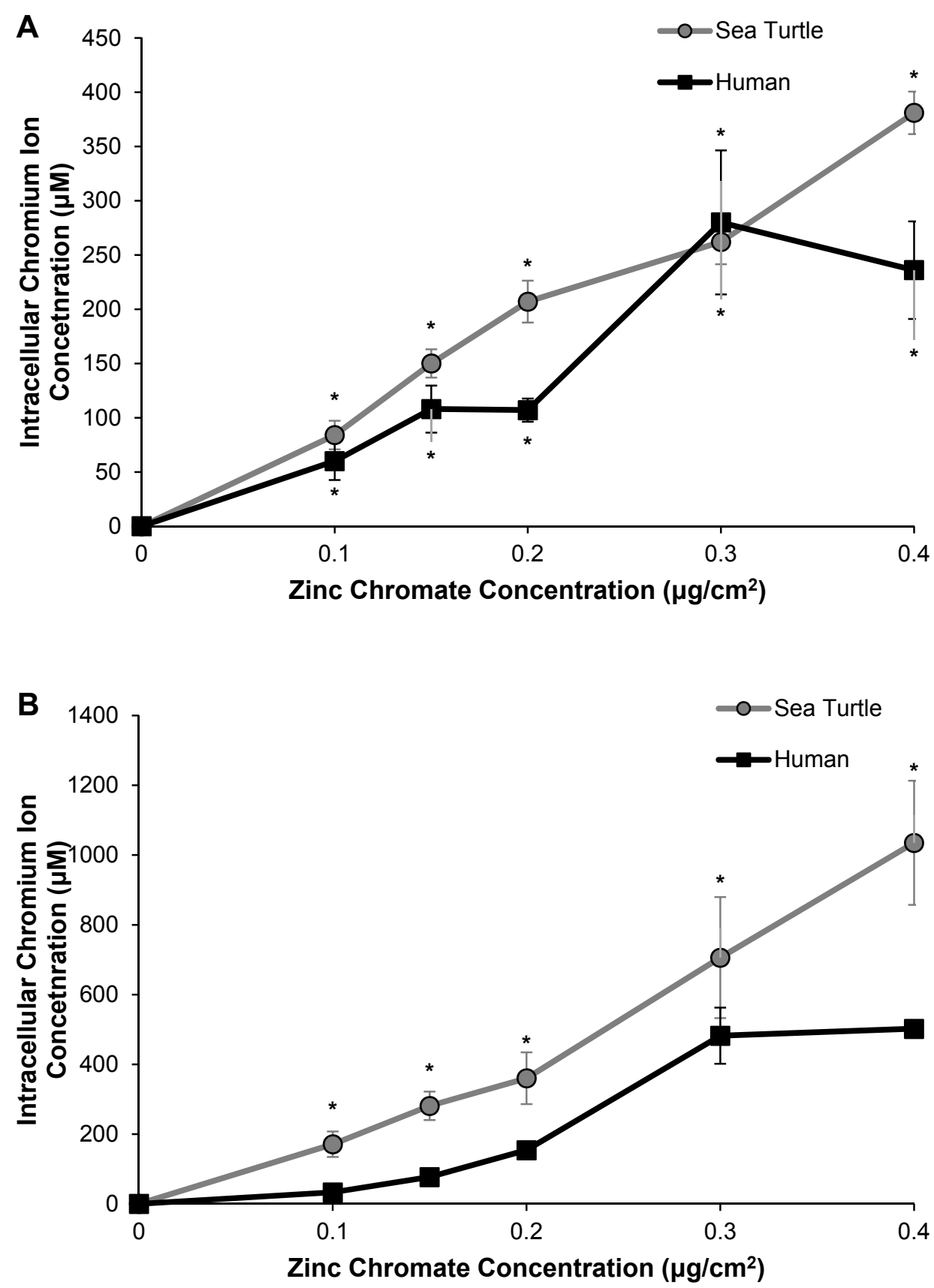

Figure 13. Leatherback Sea Turtle and Human Lung Cells Accumulate Similar Levels of Intracellular Chromium after 24 and $120 \mathrm{~h}$ Exposure

This figure shows that with increasing particulate zinc chromate treatments, intracellular chromium ion concentrations increase in a concentration-dependent manner after 24 and $120 \mathrm{~h}$ exposure in leatherback sea turtle and human lung cells. Data represent an average of at least three independent experiments \pm standard error of the mean ${ }^{\dagger}$. ${ }^{*}$ Statistically significant compared to control $(p<$ 
0.05). a) $24 \mathrm{~h}$. b) $120 \mathrm{~h}$. 'Data represent an average of two independent experiments for the human $120 \mathrm{~h}$ intracellular chromium ion concentrations.

4.4 Particulate Hexavalent Chromium Induces Similar Trends in Cytotoxicity and Genotoxicity in Leatherback Sea Turtle and Human Lung Cells

In addition to comparing the effects of zinc chromate based on treatment concentrations comparisons based on intracellular chromium ion concentration were also performed. Based on these intracellular chromium ion concentrations particulate zinc chromate induce similar levels of cytotoxicity (Figure 14A and 14B). For example, at the $24 \mathrm{~h}$ time point an intracellular chromium ion concentration of $262 \mu \mathrm{M}$ reduced relative survival to 33.2 percent in turtles while an intracellular chromium ion concentration of $280 \mu \mathrm{M}$ following reduced relative survival to 41.4 $\%$, in humans.

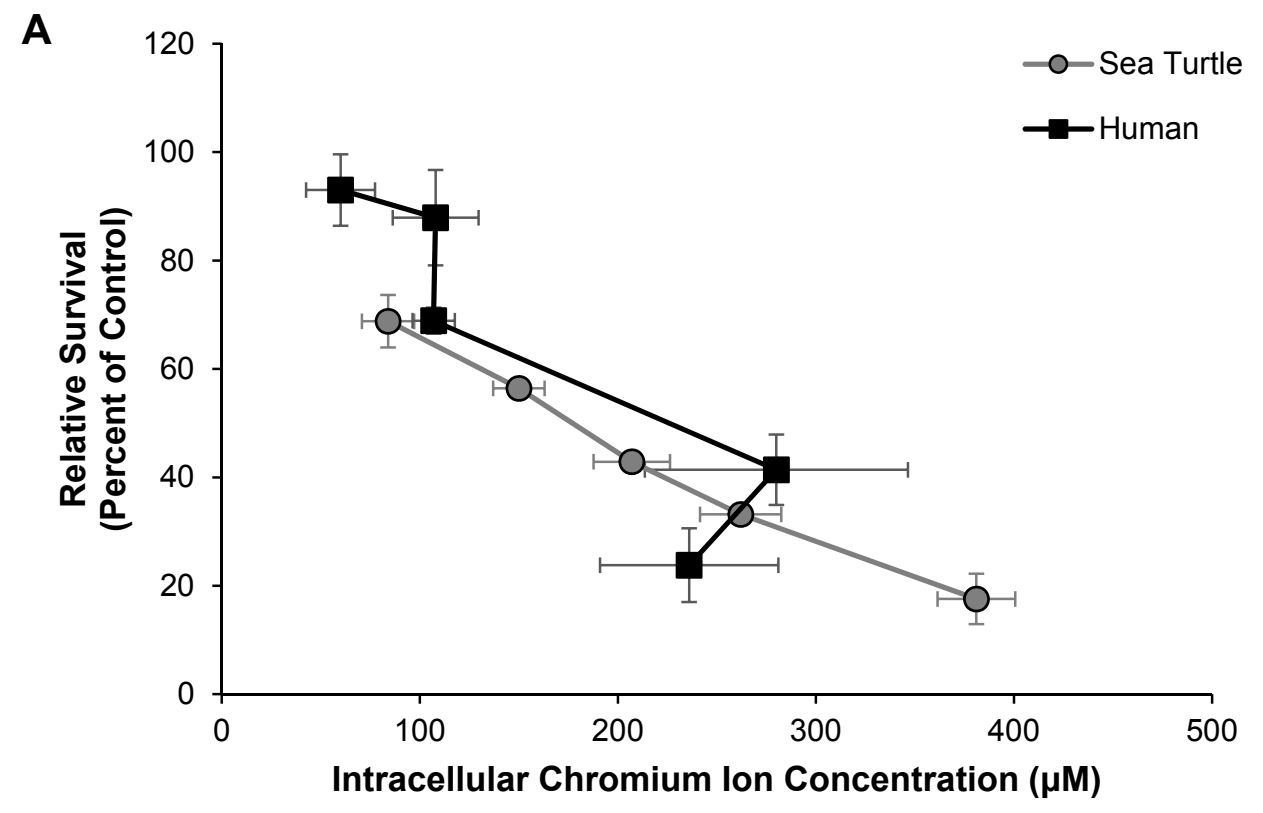




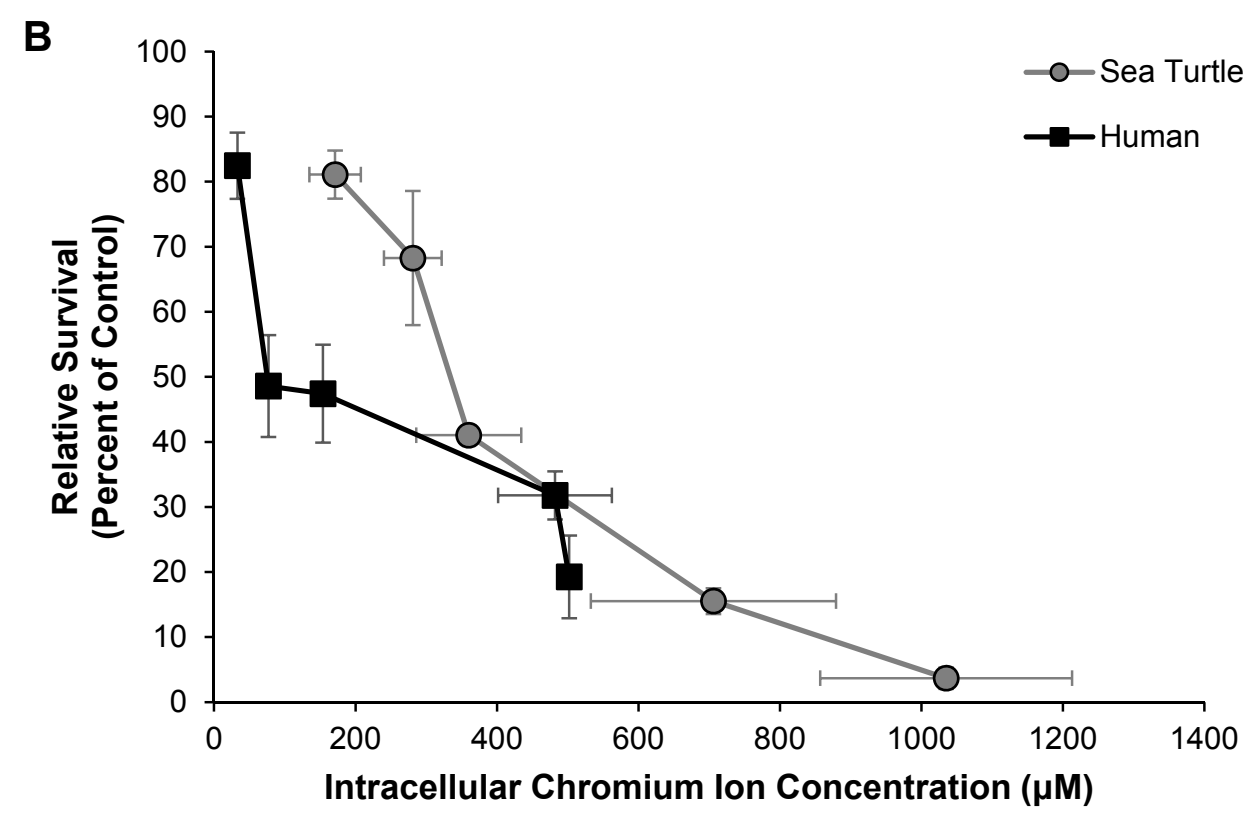

Figure 14. Particulate Chromate Induces Similar Trends of Cytotoxicity in
Leatherback Sea Turtle and Human Lung Cells.

This figure shows that at similar levels of intracellular chromium ion concentrations particulate chromate induces similar trends in cytotoxicity in leatherback sea turtle and human lung cells. a) $24 \mathrm{~h}$. b) $120 \mathrm{~h}$. Data represent an average of at least three experiments \pm standard error of the mean ${ }^{\dagger}$. †Data represent an average of two independent experiments for the human $120 \mathrm{~h}$ intracellular chromium ion concentrations.

Similar to the cytotoxicity, the genotoxicity of zinc chromate using the intracellular chromium ion concentrations measured by AAS was assessed. After $24 \mathrm{~h}$ exposure, zinc chromate was slightly more genotoxic to sea turtle lung cells compared to human lung cells (Figure 15A). For example, an intracellular chromium ion concentration of $150 \mu \mathrm{M}$ resulted in 23.3 percent of metaphases with damage in sea turtle lung cells while an intracellular chromium ion concentration of $108 \mu \mathrm{M}$ resulted in 35 percent of metaphases with damage in human lung cells. However, after $120 \mathrm{~h}$ exposure zinc chromate induced a very similar frequency of cells with damage in sea turtle and human lung cells. For example, at an 
intracellular chromium ion concentration of $171 \mu \mathrm{M}$ the percent of metaphases with damage was 28 in sea turtle lung cells while an intracellular chromium ion concentration of $154 \mu \mathrm{M}$ also induced 28 percent of metaphases with damage in human lung cells.

A

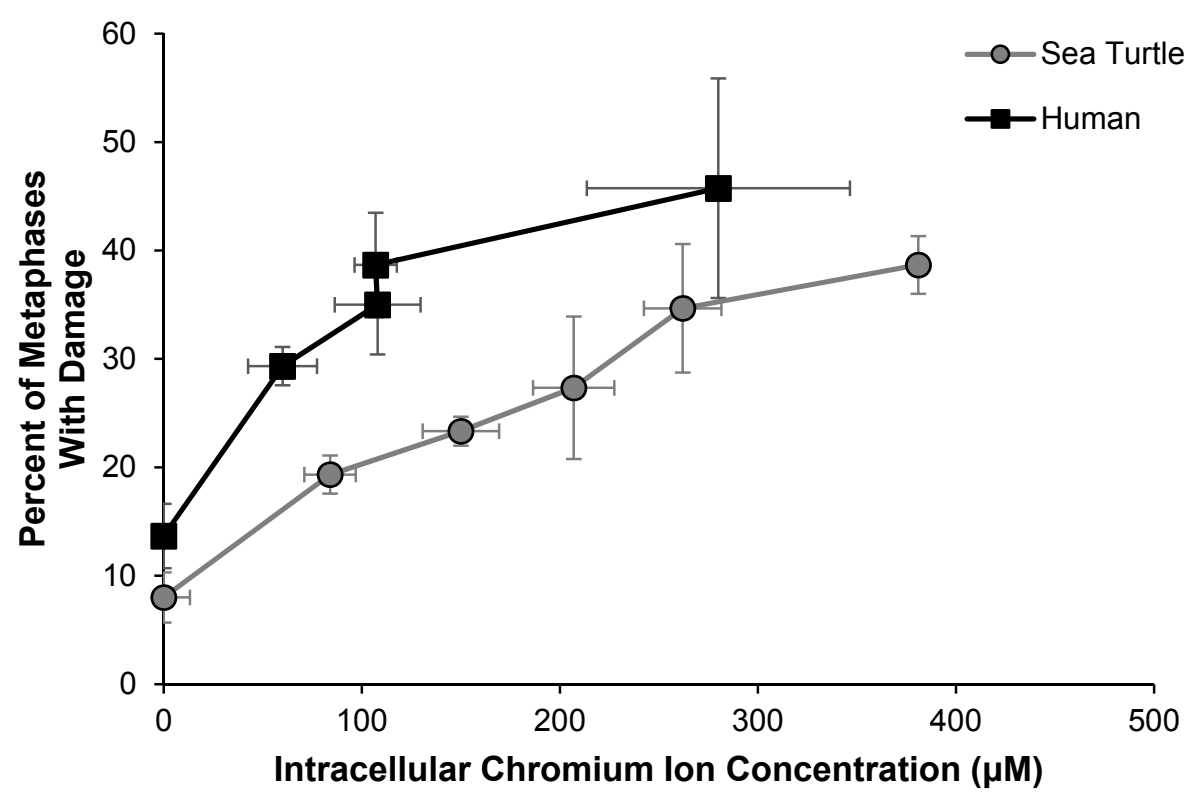

B

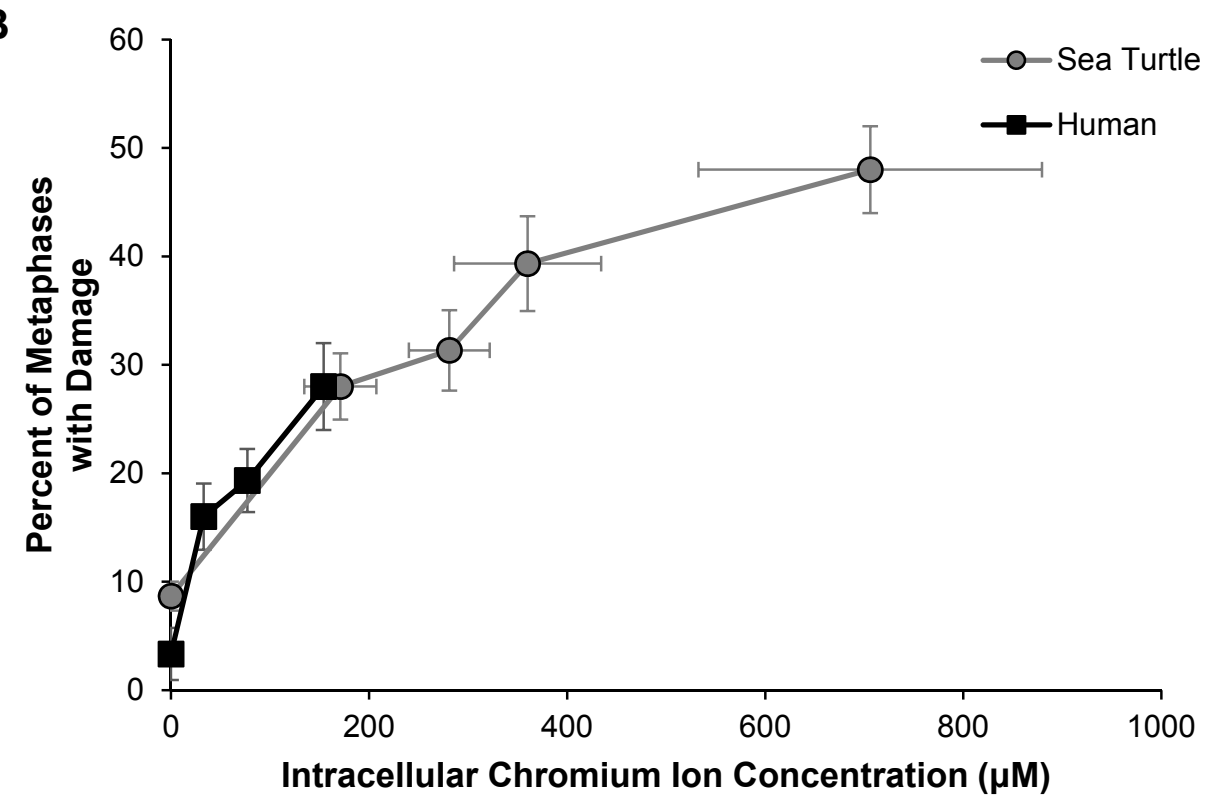


Figure 15. Particulate Chromate Induces Similar Levels of Genotoxicity in Leatherback Sea Turtle and Human Lung Cells.

This figure shows that at similar levels of intracellular chromium ion concentrations particulate chromate induces a similar frequency of cells in leatherback sea turtle and human lung cells. a) 24 h. b) 120 h. Data represent an average of at least three experiments \pm standard error of the mean ${ }^{\dagger}$. †Data represent an average of two independent experiments for the human $120 \mathrm{~h}$ intracellular chromium ion concentrations. 


\section{CHAPTER 5: DISCUSSION}

In this study a One Health approach was used to address the health risks associated with the global environmental contaminant $\mathrm{Cr}(\mathrm{VI})$. The One Health approach is a research strategy that incorporates human health, wildlife health, and ecosystem health in order to establish a more comprehensive understanding of global health. Traditionally, the One Health approach has been used to investigate the spread of disease [1-4]. However, more and more this approach is being used to evaluate health risks associated with environmental contaminants. Environmental contaminants such as $\mathrm{Cr}(\mathrm{VI})$ are excellent candidates to study in the One Health approach because they often affect human health, wildlife, and ecosystem health independently as well as interdependently [53,54]. $\mathrm{Cr}(\mathrm{VI})$ for example is a known human lung carcinogen which also has reproductive, immunological, and developmental toxicities $[11,22,23]$. Human data on $\mathrm{Cr}(\mathrm{VI})$ toxicities provides insight into how $\mathrm{Cr}(\mathrm{VI})$ in the environment may be affecting the leatherback sea turtle population. Data concerning the levels of $\mathrm{Cr}$ in leatherback sea turtle tissues can provide information about environmental exposures to $\mathrm{Cr}(\mathrm{VI})$ and how they may contribute to human health. Finally, comparison studies between humans and wildlife species provide data that is informative for evaluating risk assessment and uncovering mechanistic differences between species that may lead to treatment therapies. In this study, the One Health approach provided 
intriguing and valuable data that will advance our understanding of $\mathrm{Cr}(\mathrm{VI})$ toxicities and carcinogenicity.

The importance of studying $\mathrm{Cr}(\mathrm{VI})$ in the health of leatherback sea turtles is further exemplified by their critically endangered status [40]. Leatherback sea turtles face many anthropogenic challenges which include exposure to environmental contaminants $[42,43,55,56]$. These challenges may contribute to the low reproductive success rates of leatherback sea turtles or compromise their development. Indeed, only 1 in 1000 leatherback sea turtles reach reproductive age [38]. Additionally, leatherback sea turtle exposure to contaminants is potentially exacerbated by the fact that leatherbacks are large and long lived marine reptiles which increases their risk of repeated toxic insult and accumulation of contaminants. Accordingly, in this study $\mathrm{Cr}(\mathrm{VI})$ was evaluated in leatherback sea turtles using both acute and prolonged exposures.

Only one study has measured $\mathrm{Cr}$ levels in leatherback sea turtle tissues, however this study did not evaluate $\mathrm{Cr}$ levels in the lung [47]. Interestingly, a hawksbill sea turtle study showed that the highest levels of $\mathrm{Cr}$ were in the lungs compared to liver, kidney, and muscle further suggesting sea turtles may be at risk to $\operatorname{Cr}(\mathrm{VI})$ exposure in the lung [48]. Leatherback sea turtles are air breathing animals who hold their breath for long periods of time during deep dives to forage which creates added pressures and potentially increases risks associated with $\mathrm{Cr}(\mathrm{VI})$ inhalation [28]. An interesting study reported marine animals may be exposed to higher levels of air pollutants because these pollutants have a tendency to concentrate at the water-air interface [57]. The pressure and extended period of time leatherbacks 
hold their breath increases the amount of time the lung tissue may be exposed to airborne pollutants including $\mathrm{Cr}(\mathrm{VI})$. Furthermore, the lung is specifically known to be a target of $\mathrm{Cr}(\mathrm{VI})$ exposure, and in humans $\mathrm{Cr}(\mathrm{VI})$ is a known lung carcinogen [11]. This study is the first to investigate $\mathrm{Cr}(\mathrm{VI})$ in leatherback sea turtles. Considering the breathing behavior of leatherbacks, their potential inhalation exposure, and the fact that $\mathrm{Cr}(\mathrm{VI})$ is a lung carcinogen lung cells were used in this study. Previous studies have shown that metals such as cobalt, nickel, and $\mathrm{Cr}$ can have varying toxic effects based on the solubility of the metals $[5,6,16,17,58,59]$. Therefore, both soluble and particulate forms of $\operatorname{Cr}(\mathrm{VI})$ were included in the analysis to account for this possibility.

The first goal of this study was to investigate the cytotoxicity of chromate compounds in leatherback sea turtle lung cells. All three chromate compounds, soluble sodium chromate, particulate zinc chromate, and particulate lead chromate, induced a concentration dependent increase in cytotoxicity after $24 \mathrm{~h}$ exposure. The levels of cytotoxicity caused by $\mathrm{Cr}(\mathrm{VI})$ exposure were assessed in a previous study using hawksbill sea turtle skin cells [50]. That study also found that both soluble and particulate $\mathrm{Cr}(\mathrm{VI})$ were cytotoxic in hawksbill sea turtles. The same assays were used to assess cytotoxicity in hawksbill sea turtles, however, when compared to our results in leatherback sea turtles, hawksbill sea turtles were slightly more sensitive the cytotoxic effect of $\mathrm{Cr}(\mathrm{VI})$ exposure. One other study evaluated $\mathrm{Cr}(\mathrm{VI})$ cytotoxicity in sea turtle cells [60]. That study measured the cytotoxicity of soluble $\mathrm{Cr}(\mathrm{VI})$ in green sea turtles and found that $\mathrm{Cr}(\mathrm{VI}) \mathrm{IC} 50$ values indicated high levels of cytotoxicity. The green sea turtle study included cell lines 
from several different tissues including lung, liver, and testes which all showed similar trends. To summarize, the results reported in this study in leatherback sea turtle cells support the cytotoxicity data of the two other studies that have investigated $\mathrm{Cr}(\mathrm{VI})$ cytotoxicity in sea turtle cells that showed $\mathrm{Cr}(\mathrm{VI})$ compounds are cytotoxic to sea turtle cells.

Next, the genotoxicity of chromate compounds was investigated in leatherback sea turtle lung cells in order to understand further the underlying mechanisms of $\mathrm{Cr}(\mathrm{VI})$ toxicity in leatherback sea turtles. A chromosome aberration assay directly revealed that soluble and particulate chromate compounds were genotoxic to leatherback sea turtle cells. All three chromate compounds induced a concentration-dependent increase in chromosome damage following $24 \mathrm{~h}$ exposure. This finding suggests that $\mathrm{Cr}(\mathrm{VI})$ may have serious implications in the genomic integrity of leatherback sea turtle cells. The genotoxicity of $\mathrm{Cr}(\mathrm{VI})$ was also assessed in the hawksbill sea turtle study which showed a similar trend in response observed in the leatherback sea turtles [50]. However, in the hawksbill sea turtle study there were no metaphases at $5 \mu \mathrm{M}$ sodium chromate and $5 \mu \mathrm{g} / \mathrm{cm}^{2}$ lead chromate whereas in leatherback sea turtles chromosome damage continued to increase. This result indicates that while $\mathrm{Cr}(\mathrm{VI})$ compounds have similar genotoxic effects across sea turtle species, there are slight differences in the levels of toxicity that remain to be understood.

$\mathrm{Cr}(\mathrm{VI})$ compound toxicities are dependent on the internalization and subsequent reduction of $\mathrm{Cr}(\mathrm{VI})$ to $\mathrm{Cr}(\mathrm{III})$ [61]. Additionally, previous studies have shown that the uptake of $\mathrm{Cr}(\mathrm{VI})$ is dependent on the chromate compound, the species, and 
also the tissue from which cells are derived $[5,6,7,21]$. Since this study was the first to evaluate $\mathrm{Cr}(\mathrm{VI})$ specifically in leatherback sea turtle cells the internalization of $\mathrm{Cr}$ in leatherback sea turtle lung cells was investigated. Twenty four hour exposure to all three chromate compounds resulted in a concentration-dependent increase in intracellular $\mathrm{Cr}$ ions in leatherback sea turtle lung cells. This result proves that $\mathrm{Cr}(\mathrm{VI})$ can enter leatherback sea turtle lung cells where it has its toxic effects. Interestingly, there were higher levels of intracellular $\mathrm{Cr}$ ion concentrations following sodium chromate and lead chromate exposure compared to zinc chromate. However, the reason behind this difference is not yet known. The intracellular chromium ion concentrations reported here in leatherback sea turtle cells follows a trend similar to that which was previously reported in hawksbill sea turtle cells [50]. However, the intracellular $\mathrm{Cr}$ ion concentrations in hawksbill skin cells was much lower than those reported in this study in leatherback sea turtle cells. This may be due to species or cell type differences and further indicates that there are mechanisms of $\mathrm{Cr}(\mathrm{VI})$ toxicity that remain elusive. This is contrary to results following lead chromate exposure which resulted in very similar levels of intracellular $\mathrm{Cr}$ ion concentrations in both leatherback and hawksbill sea turtle cells. Finally, a study that investigated soluble and particulate $\mathrm{Cr}(\mathrm{VI})$ in alligator cells found that they accumulated similar levels of intracellular $\mathrm{Cr}$ following particulate chromate exposure, but lower intracellular $\mathrm{Cr}$ ion concentrations following soluble chromate exposures [58]. Together, the results of this study show that $\mathrm{Cr}$ can enter leatherback sea turtle lung cells following exposure to chromate compounds. Additionally, these results relate to previous data in the literature 
suggesting that $\mathrm{Cr}(\mathrm{VI})$ exposure is a threat to leatherback sea turtles. These results also indicate that there is much to uncover about how chromate compounds elicit their toxic effects in leatherback sea turtle cells and other species.

Soluble and particulate chromate compounds use different units of measure (i.e. $\mu \mathrm{M}$ for soluble chromate and $\mu \mathrm{g} / \mathrm{cm}^{2}$ for particulate chromate). Therefore, it is difficult to compare cytotoxicity and genotoxicity data between them directly. Due to this discrepancy and the varying levels of intracellular $\mathrm{Cr}$ ion levels following exposure to the three chromate compounds investigated this study sought to compare the cytotoxic and genotoxic effects of the chromate compounds based on intracellular $\mathrm{Cr}$ ion concentrations. Based on intracellular $\mathrm{Cr}$ ion concentrations soluble sodium chromate and particulate lead chromate induced similar levels of cytotoxicity in leatherback sea turtle lung cells. However, zinc chromate induced levels of cytotoxicity comparable to sodium chromate and lead chromate, but at intracellular $\mathrm{Cr}$ ion concentrations much lower than the other two chromate compounds. This result is very interesting because it suggests that there is a mechanism behind zinc chromate exposure that results in higher cytotoxic effects. While this result is expected as zinc chromate is a particulate chromate compound and particulate chromates are considered to be more toxic it does not explain the difference between zinc chromate and the other particulate chromate compound tested, lead chromate. Further studies will be required to understand this difference better. The results of this study are contrary to a study that showed soluble chromate was more cytotoxic to hawksbill sea turtle skin cells than particulate chromate based on intracellular $\mathrm{Cr}$ ion concentrations and another study that 
showed soluble chromate was more cytotoxic than particulate chromate using these same metrics [50].

As differences in cytotoxicity between chromate compounds based on intracellular $\mathrm{Cr}$ ion concentrations were found the genotoxicity was also assessed using this method. Similar to the cytotoxicity results, soluble sodium chromate and particulate lead chromate induced similar levels of genotoxicity based on intracellular $\mathrm{Cr}$ ion concentrations. Additionally, zinc chromate induced similar levels of genotoxicity as lead chromate and sodium chromate, but at lower intracellular $\mathrm{Cr}$ ion levels. At similar levels of chromosome damage the intracellular $\mathrm{Cr}$ ion concentration needed to elicit this response following zinc chromate exposure was almost four times lower than that of the other two chromate compounds. This result is striking and suggests that leatherback sea turtle lung cells may be much more sensitive to zinc chromate exposure. Furthermore, zinc chromate is one of the most widely used chromate compounds and therefore the risk of exposure to it in the environment may be greater. One last consideration is that zinc chromate was also shown to have higher cytotoxic and genotoxic effects in human lung cells $[62,63]$ which is consistent with the present results in the leatherback sea turtle lung cells. The results considering genotoxicity based on intracellular $\mathrm{Cr}$ ion concentration are also consistent with the hawksbill sea turtle study, however, in that study zinc chromate was not assessed [50]. Together the intracellular $\mathrm{Cr}$ ion concentration comparison provides intriguing information about the cytotoxicity and genotoxicity of chromate compounds in leatherback cells consistent with results in cells of other sea turtle species and humans. It also suggests that further comparisons between 
leatherback species may provide insight into the mechanisms behind $\mathrm{Cr}(\mathrm{VI})$ induced toxicities.

Although it is undocumented if leatherback sea turtles develop lung cancer associated with $\mathrm{Cr}(\mathrm{VI})$ exposure, the toxicological data here is informative about potential health effects from $\mathrm{Cr}(\mathrm{VI})$ exposure demonstrating that they may be at risk. The results from the experiments investigating the cytotoxicity and genotoxicity of chromate compounds in leatherback sea turtle cells has important implications in evaluating their risk to $\mathrm{Cr}(\mathrm{VI})$ exposure. These data show that the toxicities of $\mathrm{Cr}(\mathrm{VI})$ in leatherback sea turtle cells likely contribute to negative health effects. Leatherback sea turtles exposed to $\mathrm{Cr}(\mathrm{VI})$ in the environment would have to compensate for any cytotoxic and genotoxic effects they suffer from $\mathrm{Cr}(\mathrm{VI})$ exposure. Furthermore, while these effects were demonstrated in leatherback sea turtle lung cells, they may also translate to other tissues such as those involved in reproduction or immune function. $\mathrm{Cr}(\mathrm{VI})$ is also known to have negative effects in these tissues (11), and any one or combination of toxicity in cells in these tissues adds pressure to the survival of leatherback sea turtles; an already endangered and compromised species.

The second goal of the current study was to compare human and leatherback cellular responses using the One Health approach. Using this method is supported by the results in the first part of this study investigating leatherback sea turtles by providing a basis to investigate how those results compare to results in humans. Additionally, human-leatherback sea turtle comparisons were performed using zinc chromate as it was the most cytotoxic and genotoxic, and has widespread risk 
of exposure. Additionally, to emulate actual exposures better, both acute and prolonged time points in this comparison were included. First the cytotoxicity of zinc chromate based on exposure concentrations was compared between species. A similar trend in cytotoxic response following 24 and $120 \mathrm{~h}$ exposures to zinc chromate was observed (Figure 11), however, the leatherback sea turtle cells were slightly more sensitive. Similar results were obtained comparing the cytotoxicity of chromate in hawksbill sea turtle cells to human cells although these experiments were performed with different chromate compounds [7].

Next the genotoxicity of zinc chromate in human and leatherback sea turtle lung cells also were evaluated based on treatment concentration. Interestingly, after 24 $\mathrm{h}$ exposure human cells accumulated slightly more damage than leatherback sea turtle cells (Figure 12). However, after $120 \mathrm{~h}$ this result was reversed with slightly higher levels of genotoxicity occurring in leatherback sea turtle cells. The reason for this switch remains to be determined, but the change in response indicates that there are some differences in how human and leatherback cells respond to $\mathrm{Cr}(\mathrm{VI})$ exposure. It was additionally noted that there were no metaphases in the human lung cells at the highest concentration, $0.4 \mu \mathrm{g} / \mathrm{cm}^{2}$, following $24 \mathrm{~h}$ zinc chromate exposure while leatherback lung cells continued to accumulate damage. This trend continued at the $120 \mathrm{~h}$ time point where both cell lines had no metaphases at the highest concentration, but human lung cells lacked metaphases at the second highest time point where chromosome damage continued to increase in leatherback lung cells (Figure 12). Cell cycle arrest has been observed at high concentrations in other study species as well $(5,6,7,18)$. However, the mechanism 
behind this effect remains to be uncovered. One possibility is that the cells may be overwhelmed by the amount of energy required to repair genomic damage and that the high levels of damage may be inducing death signals in the cell. This result along with the switch in genotoxic sensitivity at different time points demonstrates that a DNA repair change or advantage specific to one species may be uncovered that provides insight into $\mathrm{Cr}(\mathrm{VI})$ toxicity.

After comparing the cytotoxic and genotoxic effects of zinc chromate in human and leatherback sea turtle lung cells based on treatment concentration next these comparisons were based on intracellular $\mathrm{Cr}$ ion concentrations. Similar to different chromate compounds inducing varying levels of $\mathrm{Cr}$ ion concentrations, the ability of cells from different species to internalize $\mathrm{Cr}(\mathrm{VI})$ also can vary in this respect. First, the intracellular $\mathrm{Cr}$ ion concentrations in both species were assessed and showed that after $24 \mathrm{~h}$ exposure there was no difference in the levels of intracellular $\mathrm{Cr}$ ions between species (Figure 13). However, after $120 \mathrm{~h}$ exposure there were higher concentrations of $\mathrm{Cr}$ ions in the leatherback sea turtle cells compared to human cells. Since once in the cell it is very unlikely that $\mathrm{Cr}$ can leave, this accumulation of intracellular $\mathrm{Cr}$ ions may have serious toxic implications for both species, and this risk may be increased in leatherback sea turtles. This result also demonstrates temporal- and species-specific differences in $\mathrm{Cr}$ ion uptake. The results also support previous studies showing different levels of Cr uptake between human cells and those of other species $[5,6,7,58,59]$. However, in some cases human cells internalize more $\mathrm{Cr}$, and in others cells from wildlife species have higher levels of intracellular $\mathrm{Cr}$. 
Next, intracellular $\mathrm{Cr}$ ion concentrations were assessed to compare the cytotoxicity and genotoxicity of zinc chromate between human cells and leatherback sea turtle cells. Based on intracellular $\mathrm{Cr}$ ion concentrations the cytotoxic response to $\mathrm{Cr}(\mathrm{VI})$ was normalized after 24 and $120 \mathrm{~h}$ in both cell lines. In assessing genotoxicity, after $24 \mathrm{~h}$ zinc chromate exposure chromosome damage was slightly higher in human cells compared to leatherback sea turtle cells based on the intracellular $\mathrm{Cr}$ ion concentrations. However, after $120 \mathrm{~h}$ exposure again the levels of genotoxicity were normalized between human and leatherback sea turtle lung cells based on the intracellular $\mathrm{Cr}$ ion concentrations. The one difference that became evident when looking at the intracellular genotoxicity data was that leatherback sea turtle cells continued to proliferate producing metaphases with increasing chromosome damage at intracellular $\mathrm{Cr}$ ion concentrations much higher than that of human cells. This is reflective of the cell cycle arrest observed in the human cells at lower concentrations than occurs in leatherback sea turtle cells. These data suggest that leatherback sea turtle cells escape cell death mechanism that are usually activated in response to high levels of damage to the genome. Additionally, it supports previous data that show similar differences between species in genotoxicity based on intracellular $\mathrm{Cr}$ ion concentrations. For example, in the hawksbill sea turtle study $\mathrm{Cr}(\mathrm{VI})$ induced similar levels of genotoxicity based on intracellular $\mathrm{Cr}$ ion concentrations, however that study only looked at $24 \mathrm{~h}$ exposures (7). A right whale study found results similar to those of the hawksbill study as well (6). These data indicate that there are mechanisms that are species and temporally dependent contributing to the cytotoxic and genotoxic impact of $\mathrm{Cr}(\mathrm{VI})$ exposure. Furthermore, 
these data are important for understanding how different levels of environmental exposure may impact each of these species individually, but also establishes a means to relate them to one another.

The effects of $\mathrm{Cr}(\mathrm{VI})$ in other marine species have recently been investigated due to the health concerns of environmental exposures to it that may be similar in leatherback sea turtles. The Wise Laboratory previously showed high levels of $\mathrm{Cr}$ in the skin of sperm whales in a global study [3]. These levels were comparable to or higher than $\mathrm{Cr}$ levels found in lung tissue of chromate workers who developed cancers as a result of their exposure $[62,63]$. Similarities between sperm whales and leatherback sea turtles including their range of habitat throughout all of the world's oceans, similar behaviors including diving to deep depths for extended periods of time, and their long lifespans indicate that their exposures to $\mathrm{Cr}$ may be similar. Cr levels were also at higher levels in North Atlantic right whales and Southern right whales further indicating exposure to $\mathrm{Cr}$ in the ocean environment is ubiquitous and occurs across species [59,64]. As $\mathrm{Cr}(\mathrm{VI})$ was shown here to be both cytotoxic and genotoxic to leatherback cells and that $\mathrm{Cr}$ is known to accumulate in the tissues of marine species, the next consideration in determining the risk of $\mathrm{Cr}(\mathrm{VI})$ to leatherbacks is to evaluate the levels of $\mathrm{Cr}$ in leatherback tissues.

Furthermore the mechanisms behind particulate and soluble $\mathrm{Cr}(\mathrm{VI})$ toxicity is currently being investigated primarily in human cells, but has yet to be elucidated $[65,66,66]$. However, one recent study investigated DNA repair mechanisms in North Atlantic right whales compared to humans and found the whales had a 
robust DNA repair response to $\mathrm{Cr}(\mathrm{VI})$-induced DNA double strand breaks that otherwise fails in humans [68]. These data indicate that individual species may have different mechanisms underlying their response to $\mathrm{Cr}(\mathrm{VI})$ exposure and may provide valuable information about how the toxic effects of $\mathrm{Cr}(\mathrm{VI})$ exposure may be evaded. This study also suggests that there are different mechanisms underlying $\operatorname{Cr}(\mathrm{VI})$ toxicity between humans and leatherback sea turtles. Specifically, DNA repair mechanisms may be slightly different in leatherback sea turtles than humans, and the response leatherbacks have to $\mathrm{Cr}(\mathrm{VI})$ reported here provides a basis for this hypothesis. Especially after longer exposures leatherback lung cells responded to $\mathrm{Cr}(\mathrm{VI})$ differently than human lung cells indicated by higher levels of chromosome damage and increased frequency of damage where human lung cells underwent cell cycle arrest. Additionally, the types of genomic damage observed in this study included chromatid breaks and gaps indicating that $\mathrm{Cr}(\mathrm{VI})$ induces DNA double strand breaks that may lead to permanent structural chromosome instability (CIN). CIN is a hallmark of lung cancers and can severely affect the integrity of the genome. Indeed, studies have shown $\mathrm{Cr}(\mathrm{VI})$ induces DNA double strand breaks and inhibits DNA repair pathways in human lung cells likely contributing to the carcinogenic potential of $\mathrm{Cr}(\mathrm{VI})$ exposure $[67,69]$.

When looking back at previous studies of the genotoxic effects of $\mathrm{Cr}(\mathrm{VI})$ in sperm whale cells, human cells, and hawksbill sea turtle cells there is a similar trend in the cytotoxic and genotoxic response to $\operatorname{Cr}(\mathrm{VI})[5,6,50,59]$. However, the sperm whales were the most resistant to $\mathrm{Cr}(\mathrm{VI})$-induced damage followed by the hawksbill sea turtles, and finally humans being most susceptible to damage. The 
variation in response to $\mathrm{Cr}(\mathrm{VI})$ may indicate differences in repair efficiency between species and risk to the populations. $\mathrm{Cr}(\mathrm{VI})$ induced genotoxicity in leatherbacks most similarly to hawksbill sea turtles of these three species. Differences in repair and defense mechanisms may also be true for leatherback sea turtles, but further testing is required to determine this hypothesis.

Ultimately, this study showed two results that are meaningful in assessing leatherback sea turtle health in relation to $\mathrm{Cr}(\mathrm{VI})$ exposure and also how humanleatherback sea turtle comparisons can be used in the One Health approach. First, chromate compounds were found to be cytotoxic and genotoxic in leatherback sea turtle lung cells. These results suggest that exposure to $\mathrm{Cr}(\mathrm{VI})$ is a concern for leatherback sea turtle health and warrants consideration when assessing their risk to environmental contaminants. Second, a human and leatherback sea turtle comparison found that while there are similar cytotoxic and genotoxic trends in how human cells and leatherback sea turtle cells respond to $\mathrm{Cr}(\mathrm{VI})$ exposure, there are some differences. These differences indicate that there may be underlying mechanistic differences between humans and sea turtles that can be further investigated to better understand $\mathrm{Cr}(\mathrm{VI})$ toxicity and how $\mathrm{Cr}(\mathrm{VI})$ affects these species individually. In conclusion, leatherback sea turtles fit well into the One Health model, and using leatherback cells and human cells to evaluate $\mathrm{Cr}(\mathrm{VI})$ exposures will provide a valuable research perspective in assessing $\mathrm{Cr}(\mathrm{VI})$ risk. 


\section{CHAPTER 6: SUMMARY AND CONCLUSIONS}

\subsection{Strengths of this Work}

This work is pioneering in that currently there are no data investigating the effects of $\mathrm{Cr}(\mathrm{VI})$ in leatherback sea turtles. This work contributes to the One Health approach which was coined by and is endorsed by the Center for Disease Control (CDC) as well as the American Veterinary Medical Association and other regulatory agencies. Utilizing the One Health approach is valuable in determining the risks associated with exposure to environmental contaminants like $\operatorname{Cr}(\mathrm{VI})$. Environmental contaminants can affect all three aspects of One Health; humans, wildlife, and the ecosystem. Furthermore, these three aspects of One Health are interconnected which may increase the effect they have on one another. Importantly, the information gained from humans, wildlife, and the ecosystem can be compared to one another to strengthen our understanding of how environmental contaminants affect health in general.

Rigorous methods were also used in this study to evaluate the cytotoxicity and genotoxicity of $\mathrm{Cr}(\mathrm{VI})$ in our cell culture models. The clonogenic survival assay is a gold standard in the field not only evaluating cytotoxicity of chemicals, but also the potential for the cells to proliferate. Additionally, direct measurements of genotoxicity with the chromosome aberration assay were used. Finally, $\operatorname{Cr}(\mathrm{VI})$ is known to have its toxic effects based on its internalization and subsequent 
intracellular reduction. Many studies do not take into consideration the potential for different cell types to accumulate different levels of $\mathrm{Cr}$. However, this is important because exposures induce different toxic responses depending on this factor. Therefore, they were included in this study.

\subsection{Limitations and Future Directions}

This study is limited by the fact that only cells from one tissue type in the leatherback sea turtles and humans were investigated. There are no documented cases of lung cancer in leatherback sea turtles. However, exposure to environmental $\mathrm{Cr}(\mathrm{VI})$ may have other health effects in leatherbacks that are affecting the population. Additionally, as the introduction noted no one has measured $\mathrm{Cr}$ levels in lung tissue of leatherback sea turtles so it is unknown what levels these may be. However, in the future $\mathrm{Cr}$ levels will be measured in leatherback sea turtle tissue samples including liver, lung, and skin using inductively-coupled plasma mass spectrometry (ICP-MS).

Additionally, this work requires more mechanistic data to gain a better understanding of how $\mathrm{Cr}(\mathrm{VI})$ affects both leatherback sea turtles and humans. More mechanistic data investigating how $\mathrm{Cr}(\mathrm{VI})$ exposure affects protein expression and DNA repair response in leatherback sea turtle cells will further compare $\mathrm{Cr}(\mathrm{VI})$ exposure in leatherback sea turtle cells and human cells. It will also uncover any differences in the responses between them. Whale cells are less sensitive to $\mathrm{Cr}(\mathrm{VI})$ exposure than human cells $[5,68]$. This insight prompted a closer look into why that is and how the genomic-protective system of whales may be employed to improve human health. Similarly, this approach can be applied in the leatherback sea turtle model. 


\subsection{Conclusions}

In summary, these data indicate that leatherback sea turtles are at risk of experiencing negative health effects of $\mathrm{Cr}(\mathrm{VI})$ exposure. Additionally, these effects are comparable to other marine species as well as those in humans. The literature suggests that $\mathrm{Cr}(\mathrm{VI})$ exposure has the potential to affect the reproductive and immune systems and is widely accepted as a carcinogen (11). The information gathered here indicates that leatherback sea turtles may be at risk for the detrimental health effects associated with environmental $\mathrm{Cr}(\mathrm{VI})$ exposure and may play a role in the slow recovery of their endangered population.

Additionally, a response to $\mathrm{Cr}(\mathrm{VI})$ was observed in leatherback sea turtle cells similar to those observed in other marine species $(4,5,6,7)$. Directly comparing the response of leatherback sea turtle cells and human cells to $\mathrm{Cr}(\mathrm{VI})$ showed similar cytotoxic and genotoxic responses between these two species. Therefore, leatherback sea turtles may serve as an indicator species for monitoring the health of the environment in the One Health research model. This model will improve the understanding of the health of humans, wildlife, and the ecosystem as a whole by establishing baseline data and providing multiple perspectives to evaluate the health impacts of environmental pollutants. 


\section{REFERENCES}

1. Marco, A., Lopez-Vicente, M., Perez-Mellado, V. "Arsenic Uptake by Reptile Flexible-Shelled Eggs from Contaminated Nest Substrates and Toxic Effect on Embryos." Bulletin of Environmental Contamination and Toxicology 72.5 (2004): 983-90.

2. Sakai, H., Ichihashi, H., Suganuma, H., Tatsukawa, R. "Heavy Metal Monitoring in Sea Turtles Using Eggs." Marine Pollution Bulletin 30.5 (1995): 347-53.

3. Wise Sr., J.P., Payne, R., Wise, S.S., Lacerte, C., Wise, J., Gianios, C., Thompson, W.D., Perkins, C., Zheng, T., Zhu, C., Benedict, L., Kerr, I. "A Global Assessment of Chromium Pollution Using Sperm Whales (Physeter Macrocephalus) as an Indicator Species." Chemosphere 75.11 (2009): 1461-467.

4. Wise, S.S., Shaffiey, F., Lacerte, C., Goertz, C., Dunn, J.L., Gulland, F., Aboueissa, A., Zheng, T., J.P. Wise, Sr. "Particulate and Soluble Hexavalent Chromium Are Cytotoxic and Genotoxic to Steller Sea Lion Lung Cells." Aquatic Toxicology 91.4 (2009): 329-35.

5. Chen, T.L., Lacerte, C., Wise, S.S., Holmes, A., Martino, J., J.P. Wise, Sr., Thompson, W.D. "Comparative Cytotoxicity and Genotoxicity of Particulate and Soluble Hexavalent Chromium in Human and Sperm Whale (Physeter Macrocephalus) Skin Cells." Comparative Biochemistry and Physiology Part C: Toxicology \& Pharmacology 155.1 (2012): 143-50.

6. Chen, T.L., Wise, S.S., Holmes, A., Shaffiey, F., J.P. Wise, Sr., Thompson, W.D., Kraus, S. "Cytotoxicity and Genotoxicity of Hexavalent Chromium in Human and North Atlantic Right Whale (Eubalaena Glacialis) Lung Cells." Comparative Biochemistry and Physiology Part C: Toxicology \& Pharmacology 150.4 (2009): 487-94.

7. Young, J.L., Wise, S.S., Xie, H., Zhu, C., Fukuda, T., J.P. Wise, Sr. "Comparative Cytotoxicity and Genotoxicity of Soluble and Particulate Hexavalent Chromium in Human and Hawksbill Sea Turtle (Eretmochelys Imbricata) Skin Cells." Comparative Biochemistry and Physiology Part C: Toxicology \& Pharmacology 178 (2015): 145-55.

8. Hammond, P.B., Aronson. A.L. "Lead Poisoning In Cattle and Horses In The Vicinity Of A Smelter." Annals of the New York Academy of Sciences 111.2 (2006): 595-611. 
9. Marsili, L., Maltese, S., Coppola, D., Carletti, L., Mazzariol, S., Fossi, M.C. "Ecotoxicological Status of Seven Sperm Whales (Physeter Macrocephalus) stranded along the Adriatic Coast of Southern Italy." Aquatic Conservation: Marine and Freshwater Ecosystems 24.S1 (2014): 103-18.

10. Pettine M., Millero, F.J. "Chromium speciation in seawater: The probable role of hydrogen peroxide." Limnol. Oceanogr. (1990) 35:730-736.

11. Agency for Toxic Substances and Disease Registry (ATSDR). A Toxicological Profile for Chromium. U.S. Department of Health and Human Services, Public Health Service, Agency for Toxic Substances and Disease Registry; Atlanta, GA: 2012.

12. Barnhart J. "Occurrences, uses and properties of chromium." Regul Toxicol Pharm. (1997) 26:3-7.

13. Kotas J., Stasicka Z. "Chromium occurrence in the environment and methods of its speciation." Environ Pollut. (2000)107:263-83.

14. Zhitkovich A. "Chromium in drinking water: sources, metabolism, and cancer risks." Chem Res Toxicol. (2011)24:1617-29.

15. Zhitkovich, A., Quievryn, G., Messer, J., Motylevich, Z. "Reductive activation with cysteine represents a chromium(III)-dependent pathway in the induction of genotoxicity by carcinogenic chromium( $\mathrm{VI})$." Environ Health Perspect. (2002)110:729-31.

16. Speer, R.M., The, T., Xie, H., Luoi, L., Adam, R.M., J.P. Wise Sr. "Cytotoxicity and Genotoxicity of Particulate and Soluble Cobalt in Human Urothelial Cells". Biol Trace Elem Res (2017) doi:10.1007/s12011-017-0989-z.

17. Smith, L.J., Holmes, A.L., Kandpal, S.K., Mason, M.D., Zheng, T., J.P. Wise, Sr. "The Cytotoxicity and Genotoxicity of Soluble and Particulate Cobalt in Human Lung Fibroblast Cells." Toxicology and Applied Pharmacology 278.3 (2014): 25965.

18. Wise Sr., J.P., Wise, S.S., Little, J.E. "The Cytotoxicity and Genotoxicity of Particulate and Soluble Hexavalent Chromium in Human Lung Cells." Mutation Research/Genetic Toxicology and Environmental Mutagenesis 517.1-2 (2002): 221-29.

19. Wise, S.S., J.P. Wise, Sr. "Chromium and Genomic Stability." Mutation Research/Fundamental and Molecular Mechanisms of Mutagenesis 733.1-2 (2012): 78-82.

20. Urbano, A.M., Rodrigues, C.F.D., Alpiom, M.C. "Hexavalent Chromium Exposure, Genomic Instability and Lung Cancer." Gene Therapy and Molecular Biology 12 (2008): 219-38.

21. Holmes, A.L., Wise, S.S., J.P. Wise, Sr. "Carcinogenicity of Hexavalent Chromium." Indian Journal of Medical Research (2008): 353-72. 
22. Shrivastava, R., Upreti, R.K., Seth, P.K., Chaturvedi, U.C. "Effects of Chromium on the Immune System." FEMS Immunology and Medical Microbiology 34 (2002): 1-7.

23. Subramanian, S., Rajendiran, G., Sekhar, P., Gowri, C., Govindarajulu, P., Aruldhas, M.M. "Reproductive Toxicity of Chromium in Adult Bonnet Monkeys (Macaca Radiata Geoffrey). Reversible Oxidative Stress in the Semen." Toxicology and Applied Pharmacology 215.3 (2006): 237-49.

24. Kroeker, K.J., Kordas, R.L., Crim, R., Hendriks, I.E., Ramajo, L., Singh, G.S., Duarte, C.M., Gattuso, J.-P. Impacts of ocean acidification on marine organisms: quantifying sensitivities and interaction with warming. Glob Change Biol, 19 (2013) 1884-1896.

25. Wang, Z., Wang, Y., Zhao, P., Chen, L., Yan, C., Yan, Y., Chi, Q. "Metal Release from Contaminated Coastal Sediments under Changing PH Conditions: Implications for Metal Mobilization in Acidified Oceans." Marine Pollution Bulletin 101.2 (2015): 707-15.

26. Zeng, X., Chen, X., Zhuang, J. "The Positive Relationship between Ocean Acidification and Pollution." Marine Pollution Bulletin 91.1 (2015): 14-21.

27. Ellis, A.S. "Chromium Isotopes and the Fate of Hexavalent Chromium in the Environment." Science 295.5562 (2002): 2060-062.

28. Dodge, K.L., Galuardi, B., Miller, T.J., Lutcavage, M.E. "Leatherback Turtle Movements, Dive Behavior, and Habitat Characteristics in Ecoregions of the Northwest Atlantic Ocean." PLoS ONE 9.3 (2014): 1-17.

28. IARC. Monographs on the Evaluation of Carcinogenic Risks to Humans: Chromium, Nickel and Welding. Vol. 49. International Agency for Research on Cancer; Lyons, France: 1990.

30. Agency for Toxic Substances and Disease Registry (ATSDR). Toxicological profile for Chromium. U.S. Department of Health and Human Services, Public Health Service, Agency for Toxic Substances and Disease Registry; Atlanta, GA: 2008.

31. Geisler C.D., Schmidt, D. "An overview of chromium in the marine environment." Deut. Hydrogr. Z. (1991) 44:185-196.

32. Godley, B.J., Thompson, D.R., Furness, R.W. "Do Heavy Metal Concentrations Pose a Threat to Marine Turtles from the Mediterranean Sea?" Marine Pollution Bulletin 38.6 (1999): 497-502.

33. Storelli, M.M., Marcotrigiano, G.O. "Heavy Metal Residues in Tissues of Marine Turtles." Marine Pollution Bulletin 46.4 (2003): 397-400.

34. Guirlet, E., Das, K., Thome, J.P., Girondot, M. "Maternal Transfer of Chlorinated Contaminants in the Leatherback Turtles, Dermochelys Coriacea, Nesting in French Guiana." Chemosphere 79.7 (2010): 720-26. 
35. Guirlet, E., Das, K., Girondot, M. "Maternal Transfer of Trace Elements in Leatherback Turtles (Dermochelys Coriacea) of French Guiana." Aquatic Toxicology 88.4 (2008): 267-76.

36. Perrault, J.R., Miller, D.L., Garner, J., Wyneken, J. "Mercury and Selenium Concentrations in Leatherback Sea Turtles (Dermochelys Coriacea): Population Comparisons, Implications for Reproductive Success, Hazard Quotients and Directions for Future Research." Science of The Total Environment 463-464 (2013): 61-71.

37. Perrault, J.R. "Mercury and Selenium Ingestion Rates of Atlantic Leatherback Sea Turtles (Dermochelys Coriacea): A Cause for Concern in This Species?" Marine Environmental Research 99 (2014): 160-69.

38. Stewart, K.R., Keller, J.M., Templeton, JR., Kucklick, J.R., Johnson, C. "Monitoring Persistent Organic Pollutants in Leatherback Turtles (Dermochelys Coriacea) Confirms Maternal Transfer." Marine Pollution Bulletin 62.7 (2011): 1396-409.

39. Perrault, J., Wyneken, J., Thompson, L.J., Johnson, C., Miller, D.L. "Why Are Hatching and Emergence Success Low? Mercury and Selenium Concentrations in Nesting Leatherback Sea Turtles (Dermochelys Coriacea) and Their Young in Florida." Marine Pollution Bulletin 62.8 (2011): 1671-682.

40. Kaplan, I.C. "A Risk Assessment for Pacific Leatherback Turtles (Dermochelys Coriacea)." Canadian Journal of Fisheries and Aquatic Sciences 62.8 (2005): 1710-719.

41. Perrault, J.R., Wyneken, J., Page-Karjian, A., Merrill, A., Miller, D.L. "Seasonal Trends in Nesting Leatherback Turtle (Dermochelys Coriacea) Serum Proteins Further Verify Capital Breeding Hypothesis." Conservation Physiology 2.1 (2014): 1-15.

42. James, M.C., Ottensmeyer, C.A., Myers, R.A. "Identification of High-use Habitat and Threats to Leatherback Sea Turtles in Northern Waters: New Directions for Conservation." Ecology Letters 8.2 (2005): 195-201.

43. Lewison, R.L., Freeman, S.A., Crowder, L.B. "Quantifying the Effects of Fisheries on Threatened Species: The Impact of Pelagic Longlines on Loggerhead and Leatherback Sea Turtles." Ecology Letters 7.3 (2004): 221-31.

44. Kunito, T., Kubota, R., Fujihara, J., Agusa, T., Tanabe, S. "Arsenic in Marine Mammals, Seabirds, and Sea Turtles." Reviews of Environmental Contamination and Toxicology (2008): 31-69.

45. Weir, Scott M., Jamie G. Suski, Salice, C.J. "Ecological Risk of Anthropogenic Pollutants to Reptiles: Evaluating Assumptions of Sensitivity and Exposure." Environmental Pollution 158.12 (2010): 3596-606. 
46. Mckenzie, C., Godley, B.J., Furness, R.W., Wells, D.E. "Concentrations and Patterns of Organochlorine Contaminants in Marine Turtles from Mediterranean and Atlantic Waters." Marine Environmental Research 47.2 (1999): 117-35.

47. Poppi, L., Zaccaroni, A., Pasotto, D., Dotto, G., Marcer, F., Scaravelli, D., Mazzariol, S. "Post-mortem Investigations on a Leatherback Turtle (Dermochelys Coriacea) Stranded along the Northern Adriatic Coastline." Diseases of Aquatic Organisms 100.1 (2012): 71-76.

48. Storelli, M.M., Ceci, E., Marcotrigiano, G.O. "Distribution of Heavy Metal Residues in Some Tissues of Caretta Caretta (Linnaeus) Specimen Beached Along the Adriatic Sea (Italy)." Bulletin of Environmental Contamination and Toxicology 60.4 (1998): 546-52.

49. Lam, James C.W., Tanabe, S., Chan, S.K.F., Lam, M.H.W., Martin, M., and Lam. P.K.S. "Levels of Trace Elements in Green Turtle Eggs Collected from Hong Kong: Evidence of Risks Due to Selenium and Nickel." Environmental Pollution 144.3 (2006): 790-801.

50. Wise, S.S., Xie, H., Fukuda, T., Thompson, W.D., J.P. Wise Sr. "Hexavalent Chromium Is Cytotoxic and Genotoxic to Hawksbill Sea Turtle Cells." Toxicology and Applied Pharmacology 279.2 (2014): 113-18.

51. Wise Sr., J.P. "The Mechanisms and Modulation of Lead Chromate-Induced Clastogenesis." Dissertation published by The George Washington University, Washington, DC, 1994.

52. Wise Sr., J.P., Leonard, J.C., Patierno S.R. "Clastogenesis by particulate PbCrO4 in hamster and human cells." Mutat. Res., 278 (1992), pp. 69-79.

53. Nriagu, J.O., Nieboer, E. "Chromium in the Natural and Human Environments." New York, N.Y.: J. Wiley, 1989.

54. Johnson, J., Schewel, L., Graedel, T.E. "The Contemporary Anthropogenic Chromium Cycle." Environmental Science \& Technology 40.22 (2006): 7060-069.

55. Innis, C., Merigo, C., Dodge, K., Tlusty, M., Dodge, M., Sharp, B., Myers, A., Mcintosh, A., Wunn, D., Perkins, C., Herdt, T.H., Norton, T., Lutcavage, M. "Health Evaluation of Leatherback Turtles (Dermochelys Coriacea) in the Northwestern Atlantic During Direct Capture and Fisheries Gear Disentanglement." Chelonian Conservation and Biology 9.2 (2010): 205-22.

56. Plot, V., Georges. J. "Plastic Debris in a Nesting Leatherback Turtle in French Guiana." Chelonian Conservation and Biology 9.2 (2010): 267-70.

57. Rawson, A.J., Bradley, J.P., Teetsov, A., Rice, S.B., Haller, E.M., Patton, G.W. "A Role for Airborne Particulates in High Mercury Levels of Some Cetaceans." Ecotoxicology and Environmental Safety 30.3 (1995): 309-14.

58. Wise, S.S., Wise, C., Xie, H., Guillette, L.J., Zhu, C., J.P. Wise, Sr. "Hexavalent Chromium Is Cytotoxic and Genotoxic to American Alligator Cells." Aquatic Toxicology 171 (2016): 30-36. 
59. Chen, T.L., Wise, S.S., Kraus, S., Shaffiey, F., Levine, K.M., Thompson, W.D., Romano, T., O'hara, T., J.P. Wise, Sr. "Particulate Hexavalent Chromium Is Cytotoxic and Genotoxic to the North Atlantic Right Whale (Eubalaena Glacialis) Lung and Skin Fibroblasts." Environmental and Molecular Mutagenesis 50.5 (2009): 387-93.

60. Tan, F., Wang, M., Wang, W., Alonso Aguirre, A., Lu, Y. Validation of an in vitro cytotoxicity test for four heavy metals using cell lines derived from a green sea turtle (Chelonia mydas). Cell Biol. Toxicol. 26 (2010): 255-263.

61. Wise Sr., J.P., Orenstein,J.M., Patierno, S.R. "Inhibition of Lead Chromate Clastogenesis by Ascorbate: Relationship to Particle Dissolution and Uptake." Carcinogenesis 14.3 (1993): 429-34.

62. Wise S.S., Holmes A.L., Qin Q., Xie H., Katsifis S.P., Thompson W.D. "Comparative genotoxicity and cytotoxicity of four hexavalent chromium compounds in human bronchial cells." Chem Res Toxicol. (2010):23:365-72.

63. Davies J.M. "Lung cancer mortality among workers making lead chromate and zinc chromate pigments at three English factories." Brit J Ind Med. (1984): 41:15869.

64. Martino, J., Wise, S.S. "Metal Levels in Southern Right Whales (Eubalaena Australis) from Peninsula Valdes, Argentina." Journal of Environmental \& Analytical Toxicology 03.06 (2013): 1-6.

65. Stackpole, M.M., Wise, S.S., Goodale, B.C., Duzevik, E.G., Munroe, R.C., Thompson, W.D., Thacker, J., Thompson, L.H., Hinz, J.M., J.P. Wise, Sr. "Homologous Recombination Repair Protects against Particulate Chromateinduced Chromosome Instability in Chinese Hamster Cells." Mutation Research/Fundamental and Molecular Mechanisms of Mutagenesis 625.1-2 (2007): 145-54.

66. Qin, Q., Xie, H., Wise, S.S., Browning, C.L., Thompson, K.N., Holmes, A.L., J.P. Wise, Sr. "Homologous Recombination Repair Signaling in Chemical Carcinogenesis: Prolonged Particulate Hexavalent Chromium Exposure Suppresses the Rad51 Response in Human Lung Cells." Toxicological Sciences 142.1 (2014): 117-25.

67. Browning, C.L., Qin, Q., Kelly, D.F., Prakash, R., Vanoli, F., Jasin, MJ. J.P. Wise,Sr. "Prolonged Particulate Hexavalent Chromium Exposure Suppresses Homologous Recombination Repair in Human Lung Cells." Toxicological Sciences 153.1 (2016): 70-78.

68. Browning, C.L., Wise, C.F., J.P. Wise, Sr. "Prolonged Particulate Chromate Exposure Does Not Inhibit Homologous Recombination Repair in North Atlantic Right Whale (Eubalaena Glacialis) Lung Cells." Toxicology and Applied Pharmacology (2017). 
69. Harris, H.S., Benson, S.R., Gilardi, K.V., Poppenga, R.H., Work, T.M., Dutton, P.H., Mazet, J.A.K. "Comparative Health Assessment Of Western Pacific Leatherback Turtles (Dermochelys Coriacea) Foraging Off The Coast Of California, 2005-2007." Journal of Wildlife Diseases 47.2 (2011): 321-37. 


\title{
CURRICULUM VITAE
}

\author{
Rachel M. Speer \\ Wise Laboratory of Environmental and Genetic Toxicology \\ University of Louisville \\ 505 S. Hancock Street \\ CTRB, room 527 \\ Louisville, KY 40292 \\ (502) 852-3137 \\ rachel.speer@louisville.edu
}

\section{Education}

2015-PresentPh.D. student in Pharmacology and Toxicology, University of Louisville, Louisville, KY.

Degree expected: May 2019

Areas of specialization: Genetic and environmental toxicology, metal carcinogenesis.

2014-2015 Ph.D. student in Biochemistry and Molecular Biology, University of Maine, Orono, ME. Transferred programs after first year with mentor.

2010-2013 B.S. in Biotechnology and Molecular Bioscience, Rochester Institute of Technology, Rochester, NY.

2007-2010 Non-degree seeking student, Liberal Arts, Sussex County Community College, Newton, NJ.

\section{Professional Experience}

2013-2014 Research Associate. Wise Laboratory of Environmental and Genetic Toxicology, University of Southern Maine, Portland, ME.

2013 Graduate Research Assistant. "Sound behaviour of humpback whales (Megaptera novaeangliae) on summer feeding grounds in Northeast Icelandic waters". Húsavík Research Center, University of Iceland, Húsavík, Iceland.

2012 Photo-ID Intern. Alaskan Whale Foundation and University of Alaska Southeast, Sitka Campus. Collaborative humpback whale fluke matching between the Alaskan Whale Foundation and University of Alaska catalogs. 
Field Assistant. "Abundance and Survival of Pacific Humpback Whales in a Proposed Critical Habitat Area". North Coast Cetacean Society, British Columbia, Canada.

2012

Research Assistant. "Applications of a new In vivo tumor spheroid based shell-less chorioallantoic membrane 3-D model in bioengineering research". Rochester Institute of Technology and Rochester General Hospital, Rochester, NY.

\section{Publications}

Speer, R.M., The, T., Xie, H., Liou, L., Adam, R., J.P. Wise, Sr. Cytotoxicity and Genotoxicity of Particulate and Soluble Cobalt in Human Urothelial Cells. Biol Trace Elem Res (2017) doi: 10.1007/s12011-017-0989-z.

Browning, C.L., Speer, R.M., and Wise, Sr., J.P. Molecular Mechanisms of Chromium-Induced Carcinogenesis in Mudipalli, A., Zelikoff, J.T. (Eds) Essential and Non- Essential Metals: Carcinogenesis, Prevention and Therapeutics, Springer, UK, ISBN 978-3-319-55448-8.

\section{Articles in preparation}

Speer, R.M., Young, J.L., Martin Bras, M., Barandiarin, M., Marquez-D’Acunti, L., J.P. Wise, Sr. A Comparison of the Cytotoxicity and Genotoxicity of Particulate and Soluble Hexavalent Chromium in Leatherback Sea Turtle Lung Cells.

\section{Abstracts}

Speer, R.M., Young, J.L., Wise, S.S., Raph, S.M., Martin Bras, M., Barandiarin, M., Marquez-D’Acunti, L., J.P. Wise, Sr. Using Leatherback Sea Turtles (Dermochelys coriacea) as a Model Species for Metal Toxicology Research and Public Education in Vieques, Puerto Rico.

- Accepted to be presented at the $56^{\text {th }}$ Annual Meeting of The Society of Toxicology, March, 2017.

Young, J.L., Wise, S.S., Wise, C.F., Speer, R.M., Raph, S.M. Lowers, R., Hall, C., Phillipps, L., Guillette, Jr., L.J., and Wise, Sr., J.P. Using the American alligator (Alligator mississippiensis) as a Representative Species to Study Environmental Toxicology using a One Environmental Health Approach at Kennedy Space Center.

- Presented at the proceedings of the 3rd Biennial Symposium on the Biology and Ecotoxicology of the American Alligator, 2016.

Speer, R.M., Young, J.L., Martin Bras, M., Barandiarin, M., Marquez-D’Acunti, L., J.P. Wise, Sr. A Comparison of the Cytotoxicity and Genotoxicity of Particulate and Soluble Hexavalent Chromium in Leatherback Sea Turtle (Dermochelys coriacea) Lung Cells. 
- Presented at the $9^{\text {th }}$ Annual Conference on Metal Toxicity and Carcinogenesis, October, 2016.

- Presented at Research!Louisville, University of Louisville, October, 2016.

- Presented at the Ohio Valley Specialty Section Summer Meeting of the Society of Toxicology, June, 2016.

Rossman, J., Speer, R.M., Wise, S.S., J.P. Wise, Sr. Cytotoxic and Genotoxic Effects of Hexavalent Chromate on Alligator Skin and Bronchial Fibroblasts.

- Presented at Research!Louisville, University of Louisville, October, 2016.

Speer, R.M., Young, J.L., Martin Bras, M., Barandiarin, M., Marquez-D’Acunti, L., J.P. Wise, Sr. A Comparison of the Cytotoxicity and Genotoxicity of Particulate and Soluble Hexavalent Chromium in Human and Leatherback Sea Turtle (Dermochelys coriacea) Lung Cells.

- Presented at the $47^{\text {th }}$ Annual International Association for Aquatic Animal Medicine, May, 2016.

- Presented at the $55^{\text {th }}$ Annual Meeting of The Society of Toxicology, March, 2016.

Speer, R.M., The, T., J.P. Wise, Sr. The Cytotoxicity and Genotoxicity of Particulate and Soluble Cobalt in Human Urothelial Cells.

- Presented at Research!Louisville, University of Louisville, September, 2015.

- Presented at the $54^{\text {th }}$ Annual Meeting of The Society of Toxicology, March, 2015.

\section{Seminars and Oral Presentations}

"A Comparison of the Cytotoxicity and Genotoxicity of Particulate and Soluble Hexavalent Chromium in Human and Leatherback Sea Turtle (Dermochelys coriacea) Lung Cells". $8^{\text {th }}$ Meeting of Aquatic Animal Models of Human Disease, University of Alabama, Birmingham, AL. January, 2017.

"Wise Laboratory Research in Vieques: Implications and Future Directions". Vieques Conservation and Historical Trust Speaker Series, Vieques, Puerto Rico. August, 2016.

"Developing a Thesis: The Role of E2F1 in $\mathrm{Cr}(\mathrm{VI})$ Induced Carcinogenesis". Cancer Center Colloquia Series, University of Louisville, Louisville, KY. April, 2016.

"Cytotoxicity and Genotoxicity of Particulate and Soluble Cobalt in Human Urothelial Cells". Department of Applied Medical Sciences. University of Southern Maine, Portland, ME. November, 2014.

\section{Professional Memberships \& Societies}

- Graduate Student member, National Postdoctoral Association, 2016present 
- Graduate Student Member, International Association for Aquatic Animal Medicine, 2016-present

- Graduate Student Member, American Association for the Advancement of Science, 2015-present

- Graduate Student Member, Society of Toxicology, 2014-present -Ohio Valley Regional Chapter, 2015-present -Metals Specialty Section, 2014-present -Carcinogenesis Specialty Section, 2014-present

- Past Member, Northeast Regional Chapter, Society of Toxicology, 20142015

\section{Honors and Awards}

2017 Graduate Student Council research Award, University of Louisville, $\$ 500$ award for analysis of leatherback sea turtle samples

2015 Master's Basic Science Graduate Student Award, Second place for Research!Louisville poster presentation, University of Louisville

Graduate Student Travel Award, Second place for travel to the $54^{\text {th }}$ Annual Meeting of the Society of Toxicology from the Northeast Regional Chapter of the Society of Toxicology

2014 Graduate Student Travel Support Award for travel to the $54^{\text {th }}$ Annual Meeting of the Society of Toxicology from the Maine Economic Improvement Fund, University of Southern Maine

$2008 \quad$ Phi Theta Kappa Honor Society

2007-2010 New Jersey Stars Program Scholarship Recipient

\section{Volunteer and Community Work}

2017 Poster Judge, Kentucky Science Fair, Kentucky Science Center, Louisville, KY.

2016 Volunteer, U.S. Fish and Wildlife Service beach clean-up program, Vieques, PR.

Program Assistant, Manta Environmental Summer Education Program, Vieques Conservation and Historical Trust, Vieques, PR.

Head Poster Judge, Kentucky Science Fair, Kentucky Science Center, Louisville, KY. 
Student Mentor, Science Fair Student Mentoring Session, Science Policy and Outreach Group, University of Louisville and Kentucky Science Center, Louisville, KY.

Project Assistant, Research!Louisville High School Student Graduate School Information Session, Science Policy and Outreach Group, University of Louisville and Kentucky Science Center, Louisville, KY.

2014 Event Volunteer, Annual Wild \& Scenic Film Festival, Friends of Casco Bay, Portland, ME

Volunteer, Annual beach clean-up, Environmental Health and Toxicology Club, University of Southern Maine, Portland, ME.

\section{Continuing Education}

Continuing Education Course, Society of Toxicology, "Basic Principles of Human Risk Assessment"

Webinar. New Frontiers in Chemical Carcinogenesis, Association of Scientists of Indian Origin, Society of Toxicology.

Webinar. Increasing Your Visibility and Participation in SOT as an Early Career Toxicologist, SOT Postdoctoral Assembly, Society of Toxicology.

Webinar. Postdoctoral Representative Fall Webinar, SOT Postdoctoral Assembly, Society of Toxicology.

\section{Skills and Proficiencies}

-Animal cell culture

-Atomic absorption spectrometry, Certified

-Cell line development from tissues of wildlife species

-Comet assay

-Cytotoxicity assays

-Flow cytometry

-Fluorescence microscopy

-Genotoxicity assays

-Inductively coupled plasma mass spectrometry

-Immunofluorescence assays

-Metal ion uptake assays

-qPCR

-Western blot 